\title{
Reflexões sobre a Identidade Nacional nos Choros para Piano Solo de Radamés Gnattali
}

\author{
Considerations about National Identity on the Choros \\ for Piano Solo by Radamés Gnattali
}

\author{
Raísa Farias Silveira \\ Universidade do Estado de Santa Catarina - UDESC \\ raisa.piano@gmail.com
}

\section{Guilherme Sauerbronn de Barros \\ Universidade do Estado de Santa Catarina - UDESC \\ guisauer@gmail.com}

\begin{abstract}
Resumo: A temática nacional é frequentemente abordada nos trabalhos sobre Radamés e sua obra, porém costumam referir-se isoladamente a materiais musicais oriundos de estilos/gêneros reconhecidos como portadores de brasilidade. Neste artigo a discussão se apoia nas análises literárias realizadas pelo crítico Roberto Schwarz sobre a obra Memórias Póstumas de Brás Cubas (1880-1881), nas quais o crítico encontra uma relação mimética entre a estrutura narrativa do romance o comportamento característico das classes dominantes do Segundo Reinado - o qual se projeta à frente no tempo a ponto de se tornar característica constituinte de uma identidade percebida como brasileira -. Esta descrição faz referência a uma identidade nacional que reconhecemos como mediatória, alter nativa aos conceitos correntes de nacionalismo românticoe nacionalismo modernista. Analogamente, encontramos na poética de Radamés tratamento semelhante conferido ao material musical, relação da qual se ocupa este artigo e que será discutida com apoio na análise do choro Manhosamente, composto na década de 1940.
\end{abstract}

Palavras-chave: repertório brasileiro, identidade nacional, Radamés Gnattali.

\begin{abstract}
Nationalism is a frequent topic in studies about Radamés. How ever, these usually focus exclusively on locating possible origins of musical material as derived from genres/styles which can be recognized as bearers of certain Brazilianness. The discussion presented in this paper is supported on literary analyses developed by RobertoSchwarz on the "Posthumous Memoires of Brás Cubas" [Memórias Póstumas de Brás Cubas] (1880-1881), in which a mimetic relation between the narrative structure of the novel and the characteristic behavior of Brazilian upper classes in the Second Empire (1840-1889) could be found. The behavioral pattern is consolidated and
\end{abstract}


projected forward in time to such an extent that it becomes a constituent element of an identity that is perceived as Brazilian. This description makes reference to a national identity which is mediatory in nature, and presents itself as an alternative to frequent concepts of Romantic or Modern Nationalisms. We found similar handling of musical material in Radamés' w ork, being this relation object of our study. The piece chosen for analysis is a choro for solo piano entitled Manhosamente, composed in the 1940s.

Keywords: Brazilian repertoire, national identity, Radamés Gnattali.

\section{1 - Introdução}

Este artigo propõe algumas reflexões em torno da identidade nacional na obra de Radamés Gnattali, mais especificamente no choro Manhosamente. Tratase de um recorte da pesquisa realizada entre 2014 e 2016 no Programa de PósGraduação em Música da Udesc.

A discussão toma forma apoiada nas análises literárias realizadas pelo crítico Roberto Schwarz sobre a obra Memórias Póstumas de Brás Cubas (18801881), de Machado de Assis. Nestas, o autor encontra uma relação mimética entre a estrutura narrativa do romance e o comportamento característico das classes dominantes do Segundo Reinado - o qual se projeta à frente no tempo a ponto de se tornar característica constituinte de uma identidade percebida como brasileira -. Reconhecemos nesta descrição referência a uma identidade nacional mediatória, alternativa aos conceitos correntes de nacionalismo romântico e nacionalismo modernista. Analogamente, encontramos na expressão narrativa de Radamés tratamento semelhante conferido ao material musical, relação que será discutida ao longo deste artigo.

Os choros analisados na pesquisa foram Manhosamente, Negaceando e Canhoto, em diálogo com análises anteriores sobre estas peças realizadas por Almeida (1999), Santos (2002) e Pronsato (2013). Assim, para evitar repetições, muitos dos pontos abordados pelos referidos autores não entram em discussão neste trabalho. Não obstante, estão sempre presentes como pano de fundo. Devido à sua extensão, optamos por discutir somente a análise do choro Manhosamente neste artigo.

Os três choros foram comercializados na década de 1950 pela Editora Musical Brasileira, com dedilhado e pedal de Francisco Mignone, e contêm algumas pequenas diferenças em relação às versões originais, o que sugere que as peças também foram revisadas. De todo modo, optamos por utilizar a edição sem alterações a partir do manuscrito original, disponibilizada pela Sra. Nelly Gnattali, viúva do compositor.

As peças estão entre as mais difundidas de Radamés no que se refere a repertório para piano solo, provavelmente devido à sua comercialização, mencionada acima. Elas compõem um conjunto de sonoridade relativamente 
homogênea, nas quais é possível perceber a presença de diversos estilos e linguagens, em especial referências ao choro, jazz, trechos com caráter impressionista, juntamente com escrita que alude a formações instrumentais como jazz bands e orquestra de cordas. Infere-se que o fato de o compositor ter colocado a palavra "choro" abaixo do título de cada peça indica intenção de apresentar uma obra de caráter nacional; surgiu assim o questionamento sobre a encruzilhada que se forma a partir da vinculação entre este subtítulo "choro" rótulo de um estilo/gênero instrumental que é reconhecido como portador de identidade brasileira -, a sonoridade jazzística - que remete ao estrangeiro norteamericano -, e referências a cânones da música europeia - enquanto referências a "tradição" e "erudição". Isto posto, este ensaio divide-se fundamentalmente em três partes: a primeira discorre sobre a proposta de identidade nacional através do olhar de Schwarz (2012[1990]); a segunda apresenta a análise do choro Manhosamente; e a terceira traz considerações sobre o nacional no choro em questão.

\section{2 - Roberto Schwarz e a Identidade Nacional}

Na obra Um mestre na periferia do capitalismo, Roberto Schwarz analisa a fórmula narrativa do romance Memórias Póstumas de Brás Cubas em associação à estrutura social do Brasil do Segundo Reinado, época na qual a obra de Machado de Assis foi escrita. Através das análises, observa que o caráter nacional do romance reside na maneira pela qual o personagem Brás Cubas narra a história. Para além do conteúdo descrito, o que o interessa é a fórmula narrativa que rege a obra através de um constante revezamento de poses, eque, segundo argumenta o crítico, imita o comportamento das classes dominantes brasileiras.

O Segundo Reinado é marcado pelo conflito entre tendências arcaicas e tendências modernizadoras, as primeiras pautadas na estruturação do país enquanto colônia, as segundas inspiradas no liberalismo europeu. Tal situação se configura no Brasil no período entre a Independência, declarada ainda no começo do século XIX, e a abolição da escravatura, que ocorre somente ao final do mesmo século. Ao longo deste período, a estruturação socioeconômica do país é mantida tal qual configurada durante o período colonial, porém encontra-se em contradição com o novo ideário burguês importado da Europa, que representa o progresso almejado pelas elites.

É sabido que a emancipação política do Brasil, embora integrasse a nova ordem do capital, teve caráter conservador. As conquistas liberais da Independência alteravam o processo político de cúpula e redefiniam as relações estrangeiras, mas não chegavam ao complexo socioeconômico gerado pela exploração colonial, que ficava intacto, como que devendo uma revolução. Noutras palavras

\section{MUSICA THEORICA}




\begin{abstract}
o senhor e o escravo, o latifúndio e os dependentes, o tráfico negreiro e a monocultura de exportação permaneciam iguais, em contexto local e mundial transformado. No tocante às ideias caíam em descrédito as justificações que a colonização e o Absolutismo haviam criado, substituídas agora pelas perspectivas oitocentistas do estado nacional, do trabalholivre, da liberdade de expressão, da igualdade perante a lei etc., incompatíveis com as outras, em particular com a dominação pessoal direta (Schwarz 2012, p. 36).
\end{abstract}

O cerne da conflituosa situação da elite reside justamente na oposição entre o sistema escravista e o liberalismo, já que o processo de Independência não consolidou a passagem de um sistema a outro, resultando em uma espécie de prolongamento "maquiado" do modus operandi característico da exploração colonial. É pertinente considerar este fato enquanto circunstância histórica imposta (ou facultada) à camada dominante brasileira (Schwarz 2012, p. 35) e a complexidade que advém de tal configuração. As elites da época ainda tinham no sistema escravista a base de seu sustento, ao mesmo tempo em que se inspiravam nos ideais iluministas disseminados nas academias e universida des europeias nas quais seus filhos passavam os seus anos de estudo. É dizer, enquanto a contravenção sustentava e regia a vida destas elites na prática, no plano das ideias, a norma era progressista e culta.

Enquanto o ideário liberal era necessário às feições do estado brasileiro independente e progressista, ele "não expressa nada das relações de trabalho efetivas, as quais recusa ou desconhece por princípio, sem prejuízo de conviver familiarmente com elas" (Schwarz 2012, p.38). Este quadro histórico demandava, inevitavelmente, a constante mediação entre duas ideologias contraditórias; a singularida de do caso brasileiro reside, portanto, no caráter volúvel de suas elites ideologicamente ambivalentes ${ }^{1}$, que usufruíam dos privilégios viabilizados pela sua posição no sistema escravista, ao mesmo tempo em que lançavam mão de um discurso informado em certo ideário liberal.

A volubilidade descrita por Schwarz é reconhecível como uma forma de mediação entre abismos socioculturais que caracterizam o nosso país. Na música, o samba e o choro são referências emblemáticas enquanto "pontes" entre estes abismos, ao mesmo tempo em que são ativos na produção das próprias diferenças que mantêm a separação entre eles. Os relatos de Alexandre Gonçalves Pinto (ca.1870-ca.1940), compilados no livro "O Choro: Reminiscências dos chorões antigos" (2014 [1936]) evidenciam o choro como importante espaço de mediação no cenário carioca. Os verbetes são destinados a descrever músicos, gêneros, "causos" e locais de prática do choro, a partir de uma perspectiva que destaca não somente aspectos musicais desta prática. Entre os apontamentos, menção de que muitos dos músicos eram funcionários dos

\footnotetext{
${ }^{1}$ Termo cunhado por Schwarz, refere-se à ambiguidade ideológica decorrente da situação que tratamos de discutir.
} 
Correios e Telégrafos, das bandas da Marinha ou do Corpo de Polícia, professores, autônomos (sapateiros, jornalistas, ...) entre outros, informações que apontam ao encontro entre diversos estratos sociais nesta prática musical. Há igualmente menções ao domínio de aspectos como harmonia e melodia, composição e leitura ou não de partituras, destaques à criatividade e educação clássica deste ou aquele músico. Os verbetes destinados a Chiquinha Gonzaga e Ernesto Nazareth destacam especialmente sua "finíssima educação". Fato é que as múltiplas referências musicais, sociais e históricas são distintas entre os praticantes do choro, e que são as diferenças e semelhanças entre eles que aproximam e afastam estes universos que carregam o mesmo rótulo, porém se articulam de maneiras diferentes. No tocante a Radamés, a volubilidade transparece tanto em suas obras - através da alternância entre materiais de diferentes estilos e linguagens -, quanto nos discursos que a ele se referem através da maneira como se auto define (ou como outros o definem) de forma às vezes contraditória ou ambígua.

Antes de apontar a maneira pela qual o movimento de volubilidade pode ser encontrado no choro Manhosamente, procedemos a esclarecer seu funcionamento na obra de Machado de Assis, de forma a conectar a problemática da ambivalência ideológica com uma manifestação estética.

\subsection{Volubilidade na fórmula narrativa}

Memórias Póstumas de Brás Cubas é uma coletânea de memórias narradas em primeira pessoa, cujo desenrolar se dá conforme o capricho do narrador que é, ao mesmo tempo, o protagonista. A mistura de funções leva Brás a narrar a história conforme lhe convém, interrompendo-a a esmo e propondo divagações diretamente ao leitor. Com o virtuosismo retórico de um gentleman erudito, Brás conecta temas completamente diferentes de maneira despreocupada, sem nunca realmente passar para além do superficial.

Para ilustrar o movimento de volubilidade, utilizaremos um dos trechos das Memórias analisado por Schwarz (2012, p. 18-19). Trata-se do começo do Capítulo 1, no qual Brás compara as suas memórias com o Pentateuco, cuja autoria é tradicionalmente atribuída a Moisés. Segundo o narrador, as obras diferem entre si somente pelo fato de que este começa a narrar suas memórias pela morte, enquanto aquele as inicia pelo nascimento. A audácia da comparação escancara uma similitude barata a partir de um elemento comum, que é o fato de ambos se tratarem de memórias; no entanto, o absurdo da comparação cria uma dissonância de propósitos que amplifica a diferença entre os textos. Este ar deliberado de exagero é identificado antes mesmo do Capítulo 1, na dedicatória: "ao verme que primeiro roeu as frias carnes do meu cadáver". Em forma de 
epitáfio, faz par com o próprio título, igualmente descomedido, Memórias Póstumas de Brás Cubas. Afinal, como poderia um morto escrever?

\begin{abstract}
Algum tempo hesitei se devia abrir estas memórias pelo princípio ou pelo fim, isto é, se poria em primeirolugar o meu nascimento ou a minha morte. Suposto o uso vulgar seja começar pelo nascimento, duas considerações me levaram a adotar diferente método: a primeira é que eu não sou propriamente um autor defunto, mas um defunto autor, para quem a campa foi outroberço; a segunda é que o escrito ficaria assim mais galantee mais novo. Moisés, que também contou a sua morte, não a pôs no introito, mas no cabo; diferença radical entre este livro e o Pentateuco (Machado de Assis 1994 [1881], p. 2).
\end{abstract}

O trecho acima expõe um narrador supostamente reflexivo sobre a disposição de suas Memórias, preocupado com a obra que está elaborando. Porém o excesso de goma e insistência no assunto deixam transparecer o caráter artificial destas reflexões, que "não são menos postiças que a condição de falso defunto" (Schwarz 2012, p.15). O resultado é um discurso despropositado e caricaturesco; ao mesmo tempo em que o seu conteúdo parece ser empurrado para trás da prosa culta, ele salta tanto aos olhos que provoca no leitor a sensação de que há um grande contrassenso acontecendo. Tudo aponta para o exagero, e o efeito de estranhamento decorrente da distância entre o discurso ilustrado e o conteúdo é imediato.

A velocidade da fala contribui para que as mudanças de tom e estilo ocorram na forma de intervenções, produzindo uma sensação de instabilidade e constante transição, reconhecidamente o revezamento de poses do narrador. No parágrafo citado, observamos um grande número de construções antitéticas (princípio/fim, nascimento/morte, vulgar/diferente, ...); a prosa dá-se em ritmo "estritamente binário, marcado por alternativas, paralelismos, antíteses, simetrias, disparidades" (idem, p.26). Isto ocorre repetidamente sem transição, sempre envernizado pela norma culta, o que ilustra o movimento de volubilida de que perdura ao longo de todo o romance, manifestando-se em todas as suas estruturas, tanto no conteúdo quanto na construção dos demais personagens.

Assim, a volubilidade é uma feição geral a que nada escapa, sem prejuízo de ser igualmente uma tolice bem marcada, de efeito pitoresco, localista eatrasado. Ora ela funciona como substrato e verdade da conduta humana, contemporânea inclusive, que só não reconhecem os insanos, ora como exemplo de conduta ilusória, um tanto primitiva, julgada sobre fundo de norma burguesa e utilizada como elemento de cor local e sátira. Esta incerteza de base, longe de ser um defeito, é um resultado artístico de primeira força, que dá a objetividade da forma a uma ambivalência ideológica inerente ao Brasil de seu tempo (Schwarz 2012, p. 45-46).

\title{
MUSICA THEORICA
}


Conforme apontado no começo deste ensaio, encontramos efeito semelhante na composição dos choros para piano solo de Radamés. Seguindo as diretrizes das análises propostas por Schwarz, chegamos ao movimento de volubilidade como função que pode ser percebida diretamente no discurso literário, o que possibilitou encontrarmos associações com a obra de Gnattali.

\section{3 - Os Choros para Piano Solo e a Identidade Nacional}

A problemática da análise dos choros para piano solo passa pelo reconhecimento quase tácito do seu caráter híbrido. No geral, análises sobre as obras de Radamés ocupam-se de evidenciar elementos de acordo com escolas/estilos, traçando relações entre elementos isolados e respectivas "origens". Neste sentido, saltam aos ouvidos o uso de harmonias sofisticadas que remetem ao jazz ou à música de Ravel, Stravinsky e semelhantes; os contornos melódicos e a rítmica do choro. Este tipo de análise contribuiu como base de apoio para aquela que propomos aqui, mas em nossa pesquisa procuramos dar um passo além.

$\mathrm{O}$ argumento é que, mais do que o uso de material musical que remete a diversas origens, há "pedaços" de música que aludem a estilos diferentes, os quais se alternam constantemente de forma rapsódica. Esta análise se destina a apresentar uma leitura possível sobre como os contrastes gerados por essa alternância de estilos podem ser entendidos como uma maneira pela qual o compositor lida com o aspecto identitário nacional em sua obra. Assim, buscamos reconhecer de qual forma Radamés realiza sua síntese estilística em obras que se propõem a ser brasileiras já no próprio título, porém que, conforme discutido anteriormente, não se coadunam de forma satisfatória nem com o nacionalismo romântico, nem com o nacionalismo moderno ou andradiano. Para tanto, focamos na organização formal das peças a partir do reconhecimento dos materiais e técnicas utilizadas pelo compositor, já que o que nos interessa é justamente a maneira como este articula os diversos estilos de modo a dar unidade às suas obras.

Em conexão associativa com a leitura que Schwarz realiza na análise da obra de Machado, reconhecemos que o caráter nacional dos choros está vinculado à volubilidade de Radamés na sua forma de lidar com o material musical, através de uma alternância sistemática de poses que se manifestam por mudanças de caráter que forçam seccionamentos de curta duração, os quais são reconhecíveis como pastiches de estilos variados. Cada um destes seccionamentos parece criar uma micropeça musical, uma espécie de "cena". Esta metáfora serve à compreensão de que, assim como ocorre em uma narrativa cinematográfica, uma troca de cena pode indicar diversas relações temporais, e a 
mudança de foco para outros personagens não necessariamente significa ruptura ou estagnação de tempo, e sim paralelismo entre acontecimentos que continuam a ocorrer em planos diferentes.

É interessante perceber esta relação especialmente considerando que há seções que se repetem, porém que mantêm a sensação sonora e motora de deslocamento devido à maneira pela qual estão encadeadas. As cenas foram delimitadas tendo em mente que os estilos podem ou não ser tradicionalmen te associados ao piano, dado que este é utilizado com frequência como instrumento redutor, o que nos permitiu considerar formações instrumentais distintas, como big band ou orquestra de cordas. Desta forma, consideramos que há uma relação tácita muito íntima entre estilo e instrumentação, porém que é passível de ser transposta e adaptada através do arranjo. Neste sentido, deve-se considerar que a ruptura entre cenas pode ocorrer devido a uma relação de mudança de instrumentação, já que no caso do arranjo para piano solo é muitas vezes impossível dar conta da realização simultânea da melodia, textura harmônica, linha de baixo e padrões rítmicos o tempo todo.

No entanto, não podemos reduzir as mudanças de caráter exclusivam ente a adaptações decorrentes deste tipo de procedimento, já que a combinação de parâmetros implicada na caracterização de estilos musicais é infinitamente mais complexa. Partimos assim do entendimento de Leonard Meyer (1996 [1989]) que

(...) estiloé uma replicação de patterning, seja no comportamentohumano ou nos artefatos produzidos pelo comportamento humano, que resulta de uma série de escolhas feitas dentro de um conjunto de restrições. O estilo de fala ou escrita de um indivíduo, por exemplo, é resultante, em grande parte, de escolhas lexicais, gramaticais e sintáticas feitas dentro das restrições da língua e do dialeto que ele aprendeu a usar, mas que não é ele mesmo que cria. E assim o é na música, na pintura e em outras artes. De maneira geral, poucas das restrições que limitam as escolhas são recém-inventadas ou elaboradas por aqueles que as aplicam. Ao invés, são aprendidas e adotadas como parte das circunstâncias históricas/culturais de indivíduos ou grupos. Já que as restrições permitem uma variedade de realizações, os patterns não precisam ser semelhantes em todos os aspectos para serem replicações compartilhadas, mas somente naqueles aspectos que definem as relações de pattern em questão² (op. cit., p.3).

\footnotetext{
${ }^{2}$ No original: (...) style is a replication of patterning, whether in human behavior or in the artifacts produced by human behavior, that results from a series of choices made within some set of constraints. An individual's style of speaking or writing, for instance, results in large part from lexical, grammatical, and syntactic choices made within the constraints of the language and dialect he has learned to use but does not himself create. And so it is in music, painting, and other arts. More generally, few of the constraints that limit choice are newly invented or devised by those who employ them. Rather they are learned and adopted as part of the historical/cultural circumstances of individuals or groups. Since constraints allow for a variety of realizations, patterns need not be alike in all respects in order to be shared replications, but only in those aspects that define the pattern-relationships in question (Meyer 1996 [1989], p.3).
} 
Enquanto estilos cuja identificação está diretamente vinculada ao piano como instrumento-base, encontramos referências ao ragtime e stride, bem como ao choro pianeiro. Este último localiza o choro já em sua linguagem adaptada para piano, tendo base no repertório canônico que tem como principais expoentes Chiquinha Gonzaga (1847-1933) e Ernesto Nazareth (1863-1934), e faz contraponto com outras referências ao choro de forma ampla, nas quais transparecem de forma mais marcante características de sua prática em outros instrumentos, como é o caso do baixo melódico conforme descrito por Almeida (1999, p.116-120). Apesar de não termos nos aprofundado nos meandros destas diferenças, o reconhecimento de sua existência é de extrema importância, visto que as formações instrumentais dos conjuntos carregam consigo a bagagem de referências sociais e históricas diferentes. O espaço ocupado pelo choro ao piano é sensivelmente distinto daquele ocupado por um conjunto regional, por exemplo. A partir do momento em que se percebe que Radamés faz referência a formações distintas, se reconhece também o aumento de seu potencial mediatório, à medida que possibilita ao ouvinte identificar a peça a partir de referências variadas, o que também permite que este repertório adentre ambientes diversos.

Conforme mencionado anteriormente, a escrita que alude à formação instrumental de big band também foi encontrada nos choros como redução. Vale lembrar que este tipo de formação já estava nos ouvidos dos brasileiros, celebrizado em arranjos de décadas anteriores, especialmente aqueles na voz de cantores como Ary Barroso (1903-1964) e Carmem Miranda (1909-1955), sendo assim uma dupla referência: tanto ao jazz norteamericano, quanto ao nacional "modernizado".

De fato, não se espera que as análises propostas esgotem as possibilida des de considerações no que concerne o reconhecimento dos estilos empregados, mas que sirvam a contornar uma problemática que parece perseguir as análises e comentários acerca de Radamés e obra, através do entendimento de que a diversidade de referências presentes é um princípio formal que rege a poética do compositor e dá vazão ao aspecto identitário nacional.

Os Exemplos 1a e $1 \mathrm{~b}$ apresentam a forma final da análise do choro Manhosamente, e na sequência, elaboramos uma explicação pormenorizada sobre os procedimentos que levaram a tal resultado. 


\section{Manhosamente}

Radamés Gnattali

(1906-1988)
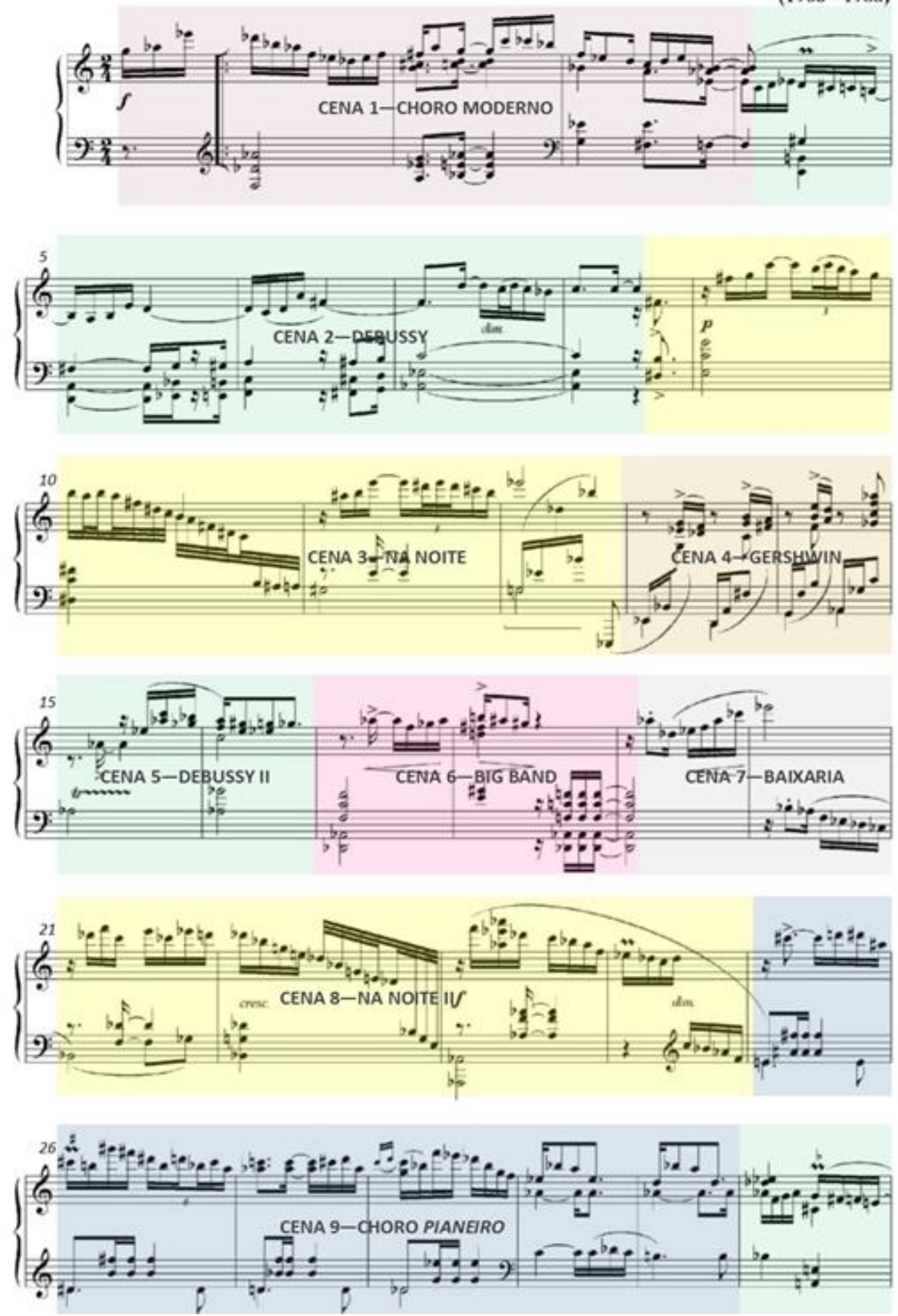

Exemplo 1a: Manhosamente, página 1

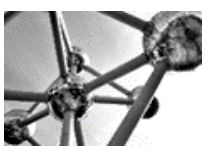





Exemplo 1b: Manhosamente, página 2

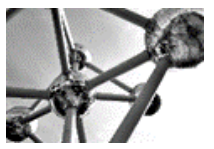


Os primeiros quatro compassos deste choro (Exemplo 2) apresentam uma melodia na região aguda com contorno semelhante a melodias de choro tradicional. No entanto, os recursos harmônicos utilizados levam a uma sonoridade distinta, motivo pelo qual o trecho foi rotulado como Choro Moderno. Santos (2002) aponta que tanto Manhosamente quanto Canhoto apresentam

(...) recursos harmônicos bastante elaborados, incluindo procedimentos e sonoridades associados ao jazz norte-americano. (...) Tais características (...) começaram a surgir na década de 1930, tendo Pixinguinha como um de seus expoentes (Santos 2002, p. 9).

O trecho começa com o que aparenta ser um acorde de $\mathrm{Db} / \mathrm{F}$ acompanhado pela melodia em escala pentatônica do mesmo acorde. Devido à ausência do IV e VII graus, neste momento fica difícil fixar uma tonalidade - poderíamos estar trabalhando tanto em $\mathrm{Db}$ quanto em $\mathrm{Ab}$ ou seus relativos menores ( $\mathrm{Bb}$ menor e $\mathrm{F}$ menor, respectivamente), considerando que a única aparição da nota Sol natural é apenas uma aproximação em tempo fraco ao Láb na anacruse para o primeiro compasso. No terceiro compasso encontramos uma modulação para a tonalidade de Eb Maior, e a frase é concluída sobre o acorde de dominante da mesma tonalidade, porém suspenso (Bb7sus4). Surgiu aqui a discussão sobre a possibilidade de esta ser uma cadência para $\mathrm{Fm} 7$, porém a primeira opção parece se confirmar tanto pela sonoridade dominante do acorde, quanto pelo fato de que o Ré no começo do compasso seguinte resolve a suspensão na terça de Bb7.

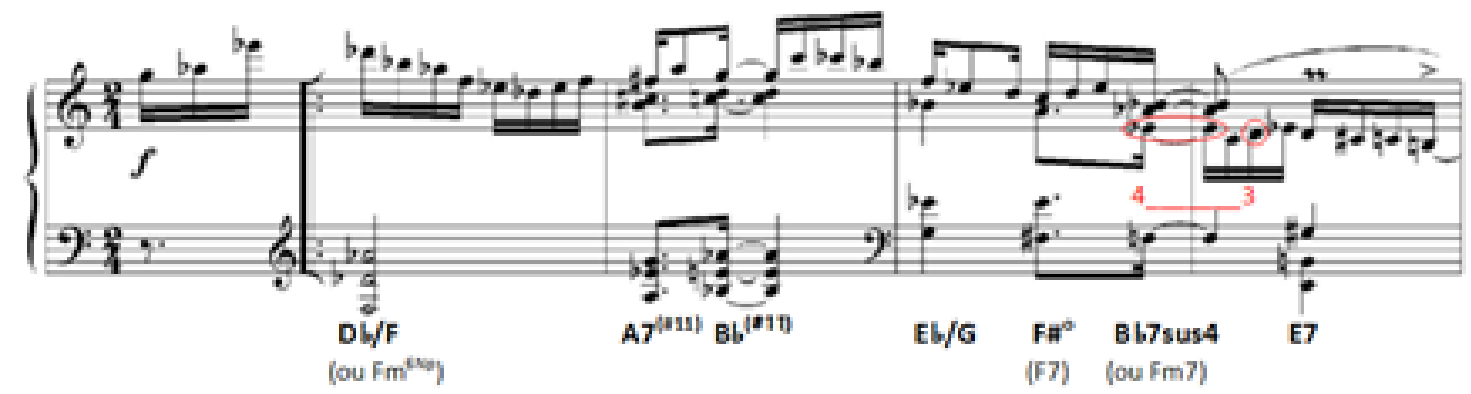

Exemplo 2: Manhosamente, compassos 1 a 4 com cadência

Pronsato (2013, p. 47-50 e 52) argumenta que é possível que toda a primeira parte entre os compassos 1 e 8 seja uma grande preparação para a chegada na área tonal de Dó Maior, o que faria com que a interpretação inicial de que estávamos num acorde de $\mathrm{Db} / \mathrm{F}$ ao começo da peça fosse substituída por um acorde de $\mathrm{Fm}^{6 \mathrm{~N} p}$, com função Subdominante, conforme o Exemplo 3. 


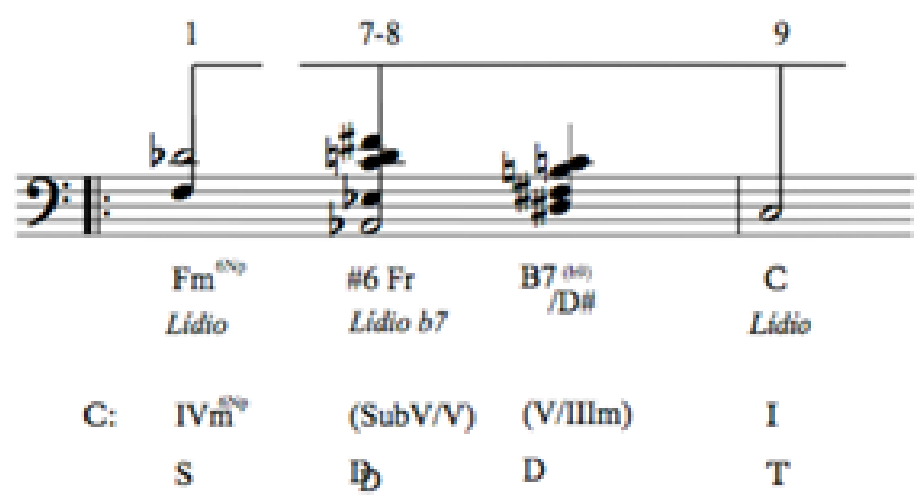

Exemplo 3: Manhosamente, análise harmônica dos compassos 1-8 Fonte: Pronsato (2013, p. 49, figura 16)

Pronsato chega a esta conclusão sobre o IVm em Dó a partir da análise da sequência harmônica que antecede o ritornelo para o começo do choro (c. 32 a 34), no qual chega-se a uma acorde de C7, que é dominante de Fm. A presença do C7 reitera a possibilidade de que o primeiro acorde, no retorno da melodia, seja de fato um $\mathrm{Fm}^{6}$ ao invés de um $\mathrm{Db}$. De todo modo, temos entre o primeiro e o quarto compassos uma frase completa, cujo delineamento se encerra com uma cadência à dominante.

Os compassos seguintes apresentam uma sequência de acordes em posição aberta com intervalos de décima na mão esquerda, que se formam entre a fundamental e a terça do acorde uma oitava acima. Este tipo de recurso é reconhecido por Santos (2002, p. 14) como prática comum ao stride piano, e substitui os intervalos de oitava utilizados ragtime, seu principal antecessor. Já Pronsato (2013, p. 41-44) sugere uma herança do virtuosismo do período Romântico, apoiando-se nos Estudos Op. 10 e Op. 25 de Frederic Chopin (18101849) e nos 51 Exercícios, de Johannes Brahms (1833-1897). Propomos uma terceira hipótese, que se soma às demais, e que considera a melodia juntamente com a movimentação paralela dos acordes com intervalos de décima. A melodia dos compassos 4 a 8 faz alusão ao tema dos primeiros quatro compassos, porém fragmentado, transposto e com uma terminação suspensa devido à condução harmônica cromática. Não chega a ser exatamente um desenvolvimento da primeira cena, parece algo mais próximo a uma dissolução do material em estilo impressionista, especialmente pela condução das vozes e pela repetição imediata da célula melódica do compasso 5. Observe-se o Exemplo 4, que apresenta os primeiros 8 compassos em questão: entre os colchetes em verde, o trecho em discussão, e em laranja, os acordes com abertura de décima. 

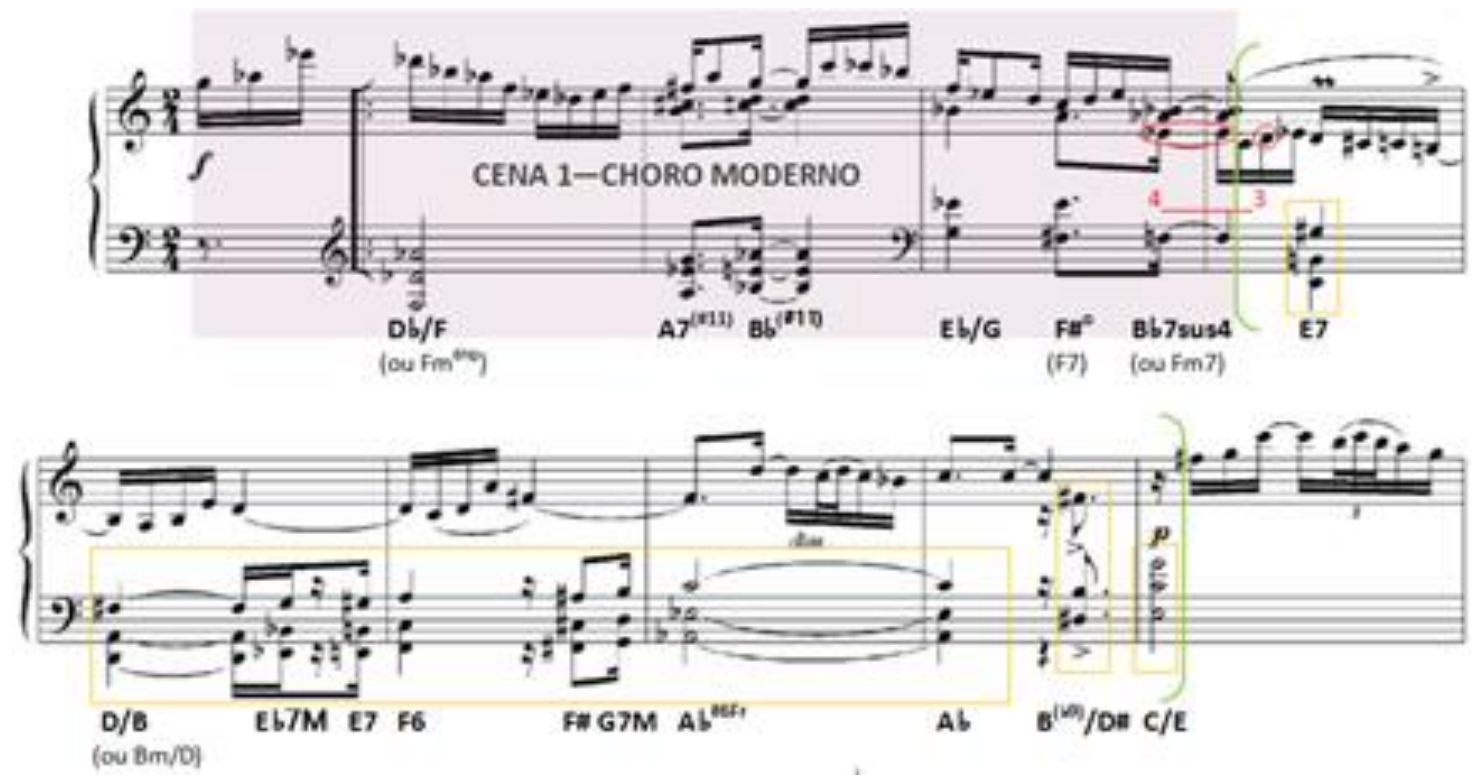

Exemplo 4: Manhosamente, compassos 1 a 8

Nesta interpretação, os acordes em décimas ajudam a enfatizar a melodia principal, ao mesmo tempo em que conduzem a uma espécie de "afastamento" tonal entre mão esquerda e mão direita. Assim, o acorde $A b^{(9, \sharp 11,13)}$ pode ser interpretado como uma sobreposição de $\mathrm{B} b$ na mão direita e $\mathrm{Ab}$ na mão esquerda no compasso 7, conforme o Exemplo 5.

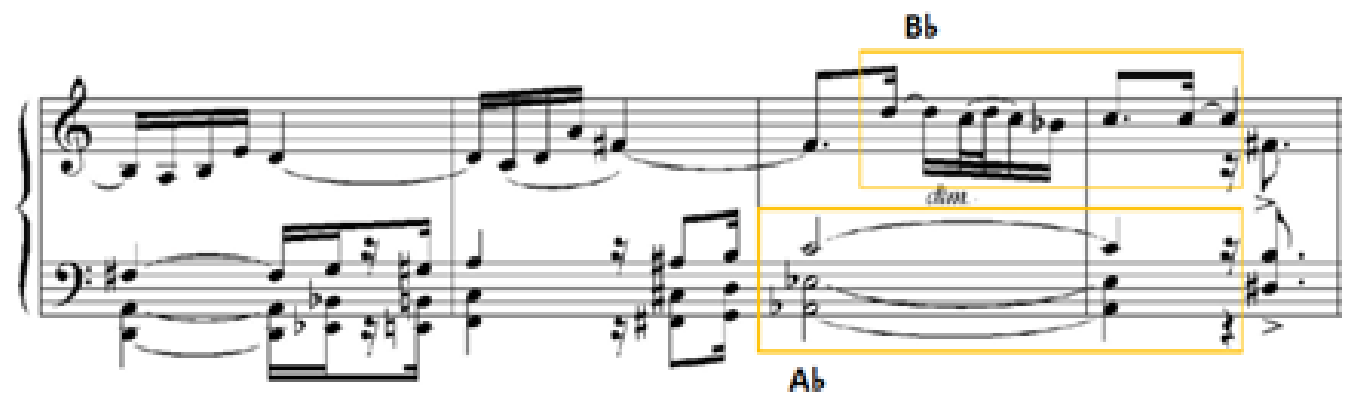

Exemplo 5: Manhosamente, sobreposição $\frac{B b}{A b}$ nos compassos 8 e 9

Percebe-se uma forte influência de Claude Debussy (1862-1918) neste trecho, tanto pelo paralelismo das décimas quanto pelo direcionamento tonal difuso. Encontramos uso semelhante em seu Prelúdio La fille aux cheveux de lin cujos compassos 14 e 15 são mostrados no Exemplo 6. 


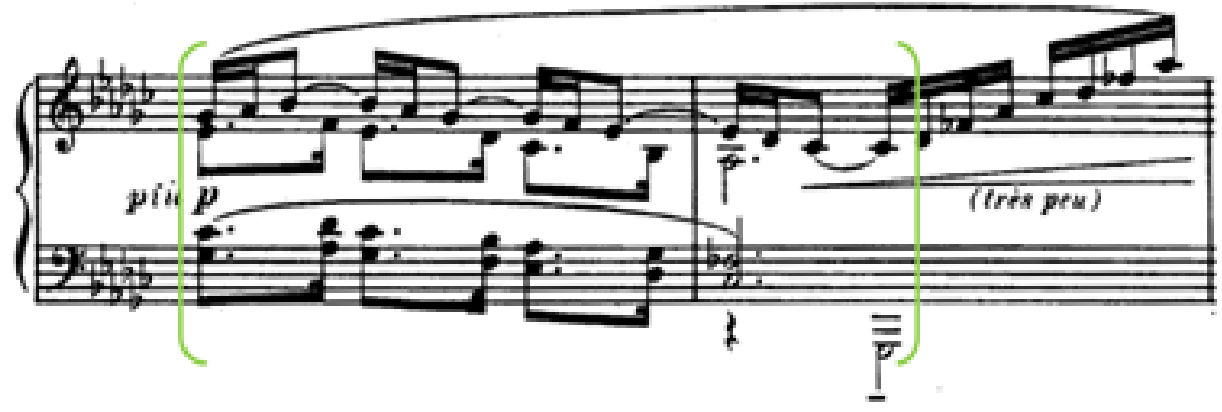

Exemplo 6: La fille aux cheveux de lin (1910) - Prelúdio VIII, Livro 1 de Claude Debussy. Uso de harmonias paralelas nos compassos 14 e 15

Embora os intervalos de décima não sejam tocados simultaneamente neste caso, a interação entre a linha melódica superior e os blocos harmônicos produz efeito bastante similar. A influência de Debussy na obra de Radamés foi reconhecida por Zorzal (2009) nas análises sobre os Dez estudos para violão (1967), nas quais evidencia características como o uso de escalas não tonais $\mathrm{e}$ instabilidade tonal: "A harmonia deixa de ser sintática e toda relação com forte sentido de processo tende a ser evitada" (op. cit., p. 39).

Denominamos o trecho entre os compassos 4 e 8 de "Cena 2 - Debussy". Após a sobreposição $\frac{B b}{A b}$ surge no finalzinho desta cena o acorde $B 7^{(b 9)} / \mathrm{D \# ,} \mathrm{com}$ clara função dominante. Esta relação dominante $\rightarrow$ tônica (c. 9-10) destoa do momento anterior, e a melodia volta à região aguda, de maneira semelhante ao começo do choro. No entanto, esta nova tentativa de retomada da melodia inicial se dilui novamente: o acorde de Dó Maior, apesar de ser um ponto de chegada importante, não logra fixar a tonalidade. Retornamos ao acorde de B7 ${ }^{(b 9)} / \mathrm{D} \#$ no compasso seguinte, agora seguido por um acorde de Mi.

Fazendo uma breve pausa na narrativa que foi construída até o momento, se olharmos para a análise harmônica, mesmo que somente neste trecho, já podemos perceber que esta peça é passível de várias leituras harmônicas. É dizer, há vários momentos claramente tonais, porém nem todos os seccionamentos possuem função tonal facilmente identificável, e o compositor joga com esta ambiguidade. Ora produz uma sensação de instabilidade ou "flutuação" tonal, onde os acordes não são conectados de forma claramente funcional, e sim subordinados à melodia principal; ora forma sequências inteiras de acordes que dão forte sensação de desenvolvimento tonal, com cadências bem marcadas. Nos trechos onde não há relações tonais claras, a estabilidade, a unidade da Cena, surge da relação com outros parâmetros. Desta forma, a realização de uma análise harmônica aprofundada pode se tornar problemática e restritiva se atribuirmos a este parâmetro demasiada importância do ponto de vista analítico. Tampouco acreditamos que este caminho seja o mais produtivo para dar conta das obras em questão, dada a proposta deste estudo. Portanto, daremos destaque 
somente àquelas harmonias que se apresentam como determinantes para 0 seccionamento da cena.

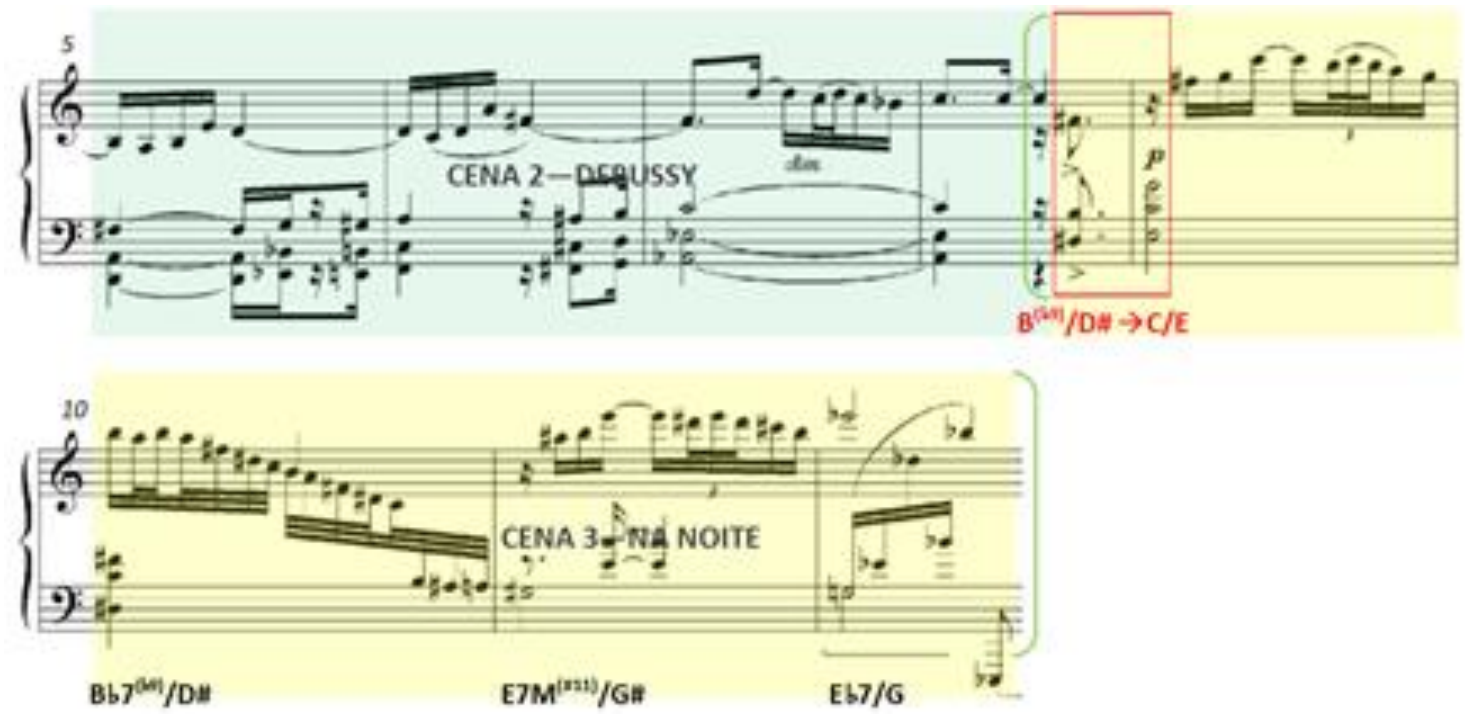

Exemplo 7: Manhosamente, compassos 5-18

Seguindo o contorno melódico dos compassos 9 a 12, grifados em amarelo no Exemplo 7, encontramos a Cena 3, composta por bordaduras e escalas com função de ornamentação e preenchimento. No compasso 10, há um arpejo de efeito sobre o acorde de $\mathrm{B} 7^{(\mathrm{b})}$. Escrito em fusas, o movimento descendente percorre uma distância um pouco maior do que três oitavas, concluindo por movimento cromático. Santos (2002, p. 14) reconhece este tipo de arpejo como comum ao stride, e aqui o reconhecemos de forma mais geral como um efeito de preenchimento com sonoridade brilhante, recurso comum também à estética de salão do século XIX. No século XX efeitos semelhantes serão utilizados amplamente por figuras como Pedrinho Mattar (1936-2007), principal representante no Brasil do estilo consagrado por Wladziu Valentino Liberace (1919-1987) nos Estados Unidos. Consiste na mistura de técnicas oriundas do piano clássico aplicadas a temas contemporâneos, bem como versões de peças do repertório erudito, envoltos com ornamentações e floreios ${ }^{3}$.

Os compassos 13 e 14 têm como característica principal o ritmo com marcação nos contratempos em um desenho melódico ascendente, com sequência harmônica que prepara o Ab7 que se prolongará nos compassos 15 e 16.

\footnotetext{
3 "Pedrinho foi atração em casas de luxo e inferninhos (...) fez sucesso no Brasil e no exterior, foi um dos grandes músicos das noites luxuosas e românticas da Baiúca" (Borelli 2005, p. 81).
} 


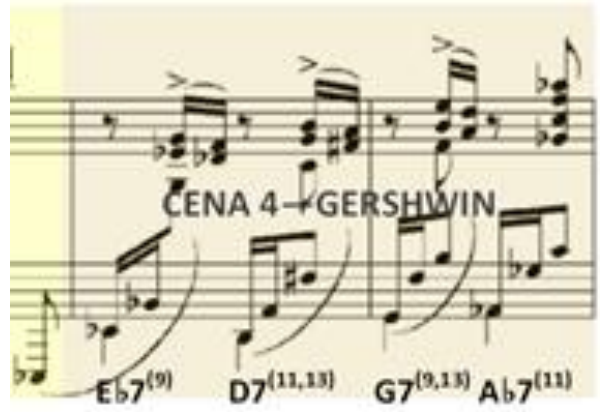

Exemplo 8: Manhosamente, compassos 13-14

Reconhecemos na Quarta Cena (Exemplo 8) uma possível influência da escrita de George Gershwin (1898-1937), compositor admirado por Radamés e com o qual este já foi por vezes comparado. Este tipo de movimento rítmicomelódico pode ser encontrado em várias de suas obras, por exemplo no caso assinalado no Exemplo 9.

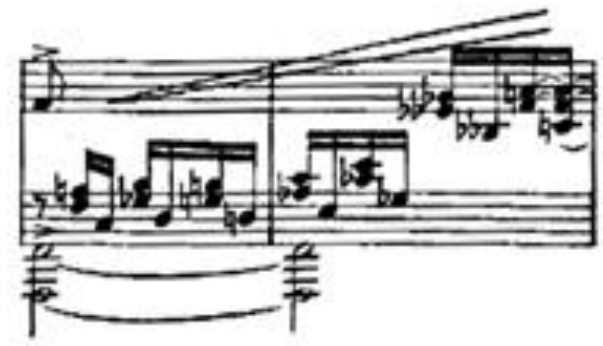

Exemplo 9: III mov. Piano Concerto in F (1925), Gershwin - compassos 37-38. Fonte: GERSHWIN, George. Concerto in F for Piano and Orchestra. Transcrição para dois pianos a quarto mãos. New York: Windsor Editions, S.D.

O fato da Cena 4 não valorizar ou aludir à síncopa - visto que o apoio está na terceira semicolcheia do tempo, e não na segunda -, favorece a conexão entre a escrita de Gershwin e a de Radamés no trecho referido. A valorização da síncopa é uma das características do choro apontado por Almeida (1999).

Em seguida, temos dois compassos em Ab7 que remetem novamente a Debussy. Desta vez, uma melodia cromática em terças paralelas é acompanhada por um trinado sobre a nota Láb na mão esquerda. O desenho lembra muito o uso das terças no Prelúdio II do Livro I - Voiles (vide Exemplo 10).

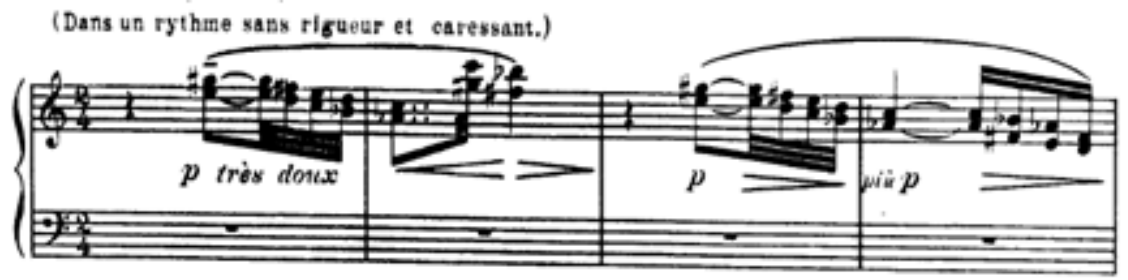

Exemplo 10: Voiles - Prelúdio II, Livro 1 (1910) de Claude Debussy. Uso de terças paralelas nos compassos 1-4. Fonte: Ed. Durand \& Cie., 1910, p. 3-6. 


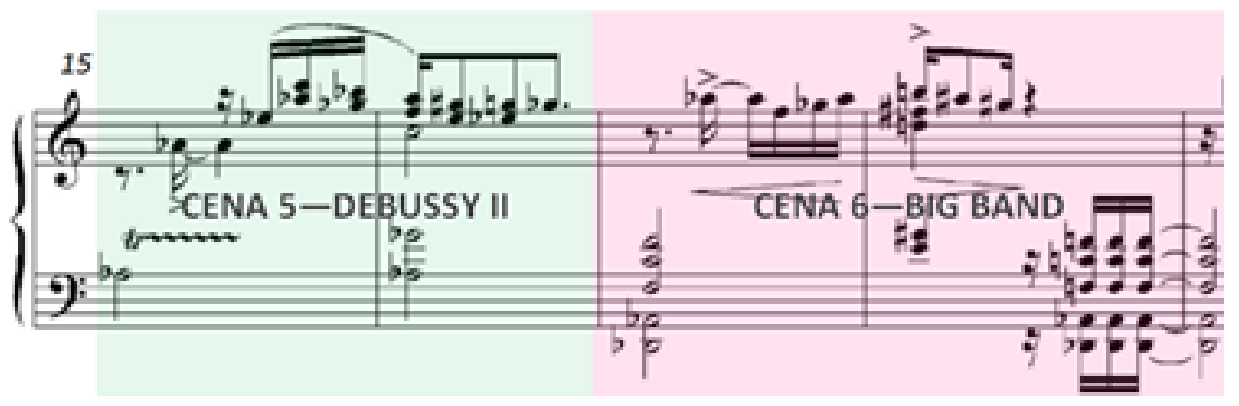

Exemplo 11: Manhosamente, cenas 5 e 6 - compassos 15-18

O contraste da Cena 5 (vide Exemplo 11) com a anterior é enorme; a prolongação do Láb combinada com o desenho melódico interrompe a sensação de direcionamento recém induzida pelas sequências de acordes bem ritmados dos compassos anteriores, amenizando a tensão do acorde dominante e criando um centro temporário em torno da nota Láb. Quando se chega à resolução no acorde de Db7M, o ouvido percebe a relação dominante $\rightarrow$ tônica, de maneira semelhante ao que ocorre na transição da Cena 2 para a Cena 3.

A sonoridade dos compassos 17 e 18 (que compõem a cena 6) se assemelha a uma conversa entre solista e orquestra, podendo os acordes da mão esquerda ao final do compasso 18 serem uma referência a algum dos naipes de sopro (madeiras ou metais), possivelmente inspirada na sonoridade das big bands.

O termo background (em inglês, "segundo plano") é muito empregado no jargão musical para designar, a grosso modo, tudo aquilo que, numa determinada peça, ocorre entre o solista (foco principal, ou primeiro plano) e a base rítmica (que seria, então, o terceiro plano) (Almada 2000, p. 281).

Esta é a primeira vez na peça que ocorre uma menção explícita a esta formação, fortemente referenciada no jazz, e antecipa a presença muito mais marcante deste estilo que ocorrerá na seção B. A resultante rítmica da melodia é praticamente igual aos dois compassos anteriores, com exceção do último tempo do compasso 18, que anuncia uma célula rítmica que será explorada mais a frente, a partir do compasso 25. É especificamente esta célula do último tempo do compasso 18 que parece revelar a escrita para seção de metais. O movimento melódico é bastante similar ao da Cena 5, e aparenta ser uma espécie de "tradução" da primeira frase de um estilo impressionista para um estilo big band.

Do ponto de vista da forma, a Cena 6, centrada em Db, é um ponto estrutural representativo na seção. Ela está localizada exatamente no meio de sua quadratura. A forma tradicional do choro consiste em agrupamentos de 16 compassos, contendo 4 frases alternadas de 4 compassos. Ao longo do século XX seções mais longas se tornam comuns, entretanto a seção A deste choro contém 34 compassos, quebrando a quadratura esperada, que costuma ser regular. 
Podemos considerar os dois compassos que "sobram" como justamente os dois que se encontram no meio da quadratura.

Os seis compassos seguintes (c. 19-24) apresentam uma transição para a próxima zona de estabilidade, que inicia no compasso 25. Nesta transição encontramos novamente ornamentações, arpejos e escalas com sonoridade brilhante como aquelas já vistas anteriormente, porém agora com algumas particularidades. Os compassos 19 e 20 trazem novamente a sonoridade do choro, ao estabelecer uma relação de diálogo entre melodia na região aguda e resposta melódica do baixo. Almeida (1999, p. 116-120) reconhece como característica recorrente do baixo melódico a rítmica do choro - com valorização da síncopa, figuras pontuadas e motivo iniciado em contratempo - e a relação de diálogo entre melodia e baixo.
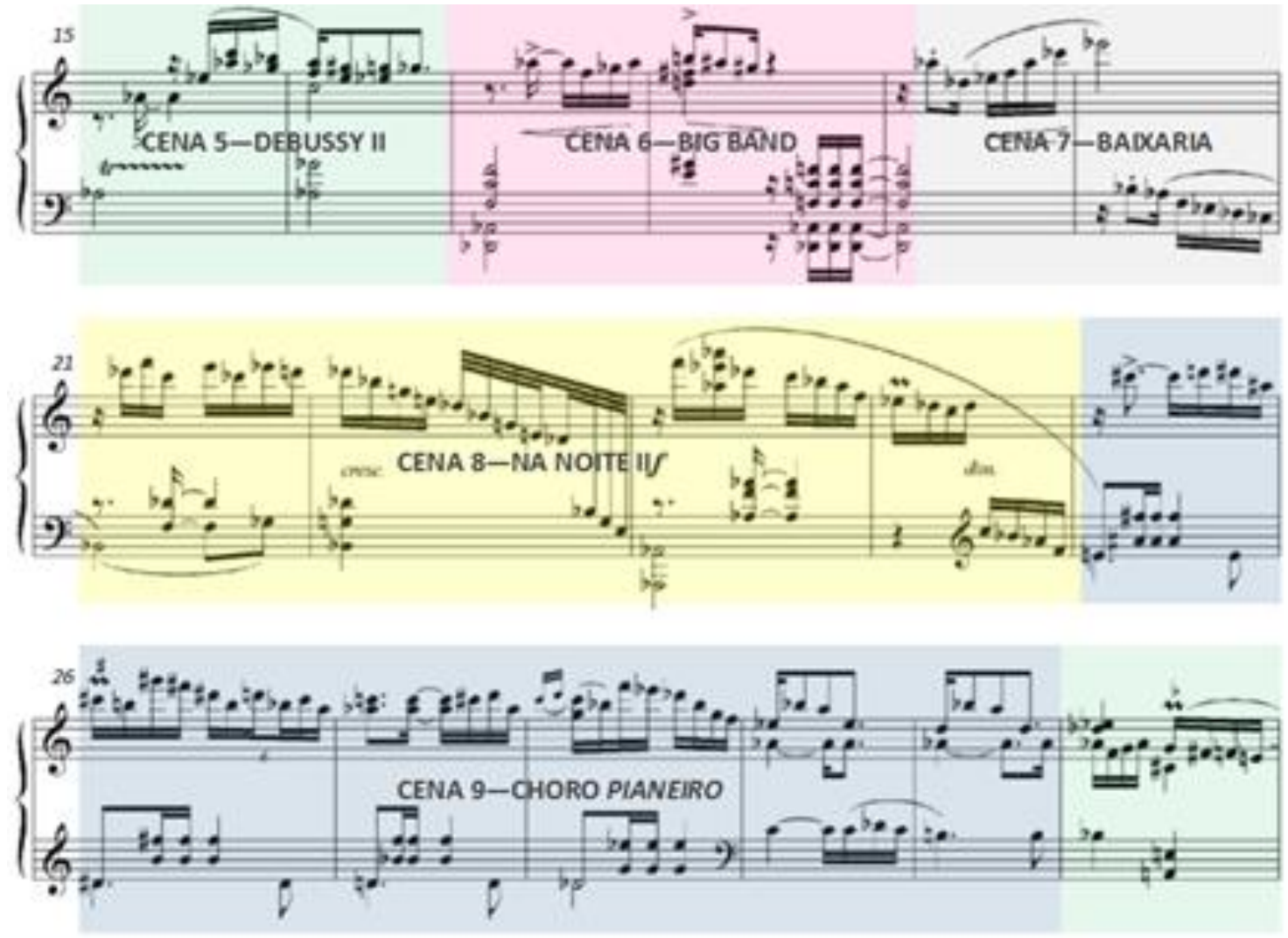

Exemplo 12: Manhosamente, compassos 15-31

Ainda conforme o Exemplo 12, entre os compassos 21 e 24 temos uma transposição a uma terça acima da linha melódica dos compassos 21-22 nos compassos 23-24. O tratamento conferido a esta cena é o mesmo que ocorre na Cena 3: a melodia que inicia no começo da Cena se dissolve em um arpejo descendente no compasso seguinte e é retomada transposta uma terça acima. Observa-se que a melodia descendente da Cena 8 desta vez logra conduzir a transição para outra zona de estabilidade. A Cena 9, entre os compassos 25 e 30 
faz alusão ao choro tradicional, notadamente àquele escrito para piano por compositores referenciais como Nazareth e Chiquinha Gonzaga. Esta caracterização já foi largamente discutida por Pronsato (2013, p. 75-79), portanto não será esmiuçada neste trabalho.

O encerramento da seção A traz novamente a Cena Debussyniana, agora transposta, para o retorno ao começo da peça. Na transição para a seção B as Cenas 1 e 2 reaparecem, com uma pequena prolongação da Cena 2, como vemos no Exemplo 13.
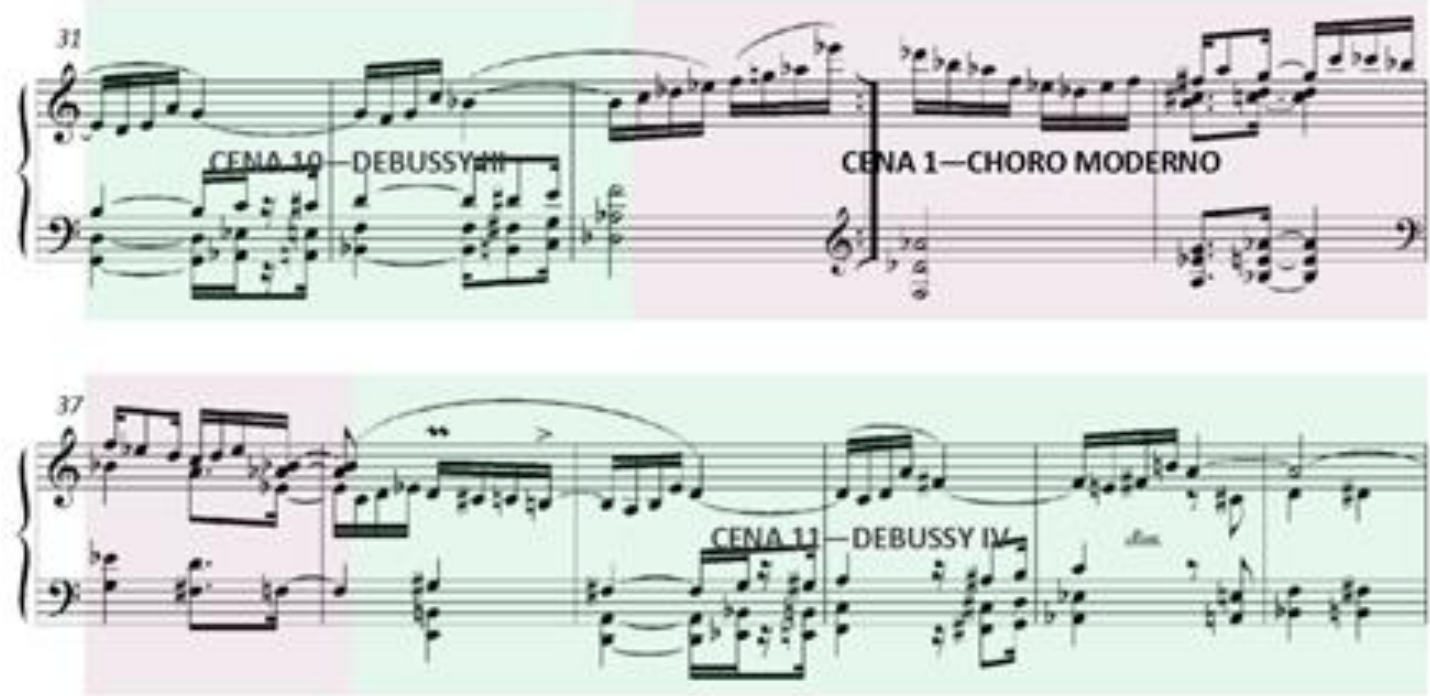

Exemplo 13: Manhosamente, finalização da seção A e transição para seção B

Temos em Manhosamente trechos de estabilidade intercalados com trechos de transição. A percepção de estabilidade está relacionada ao reconhecimento de frases/temas completos, com certa estabilidade harmônica. Olhando para as cenas de Manhosamente, fica evidente a alternância de estilos comentada no começo deste artigo. É possível ver (e ouvir) os seccionamentos, apontando para uma síntese que passa pelo que parece ser um processo de colagem, no qual os estilos se revezam na composição do conjunto. De maneira mais geral, podemos separar toda a primeira seção em duas zonas de estabilidade: o choro moderno da cena 1 e o choro pianeiro da cena 9. As demais cenas podem ser consideradas como transições.

A seção $B$ é consideravelmente mais estável do que a seção $A$, apresentando poucos seccionamentos. Os primeiros três compassos da seção introduzem uma melodia em bloco, que, conforme Santos (2002, p.13) é uma técnica que está associada à escrita para big band e bandas de música popular. Segundo Almada (2000, p. 133) este tipo de escrita, também conhecida como "soli", embora possa ser aplicada a "naipes de quaisquer classes de instrumentos, é muito mais apropriada aos sopros (...)". O autor afirma igualmente que 
(...) a total transformação naquilo que hoje conhecemos por soli só aconteceria mesmo nas orquestras de jazz americanas, nas quais a escrita coral para sopros já consagrada na música do Romantismo (século XIX) e ensinada nas classes de composição - foi novamente adaptada, desta vez ao ritmo sincopado, à harmonia e à melodia peculiares do estilo. Foi a partir daí que surgiu a, digamos assim, "regulamentação" dessa técnica, (...)" (idem, ibidem).

A cena a qual nos referimos aqui inicia com uma textura de soli fechado com 8 vozes (sendo 4 dobramentos), porém posteriormente a melodia principal é escrita com dobramentos de oitava, acompanhada na mão esquerda pelos acordes com intervalos de décima.
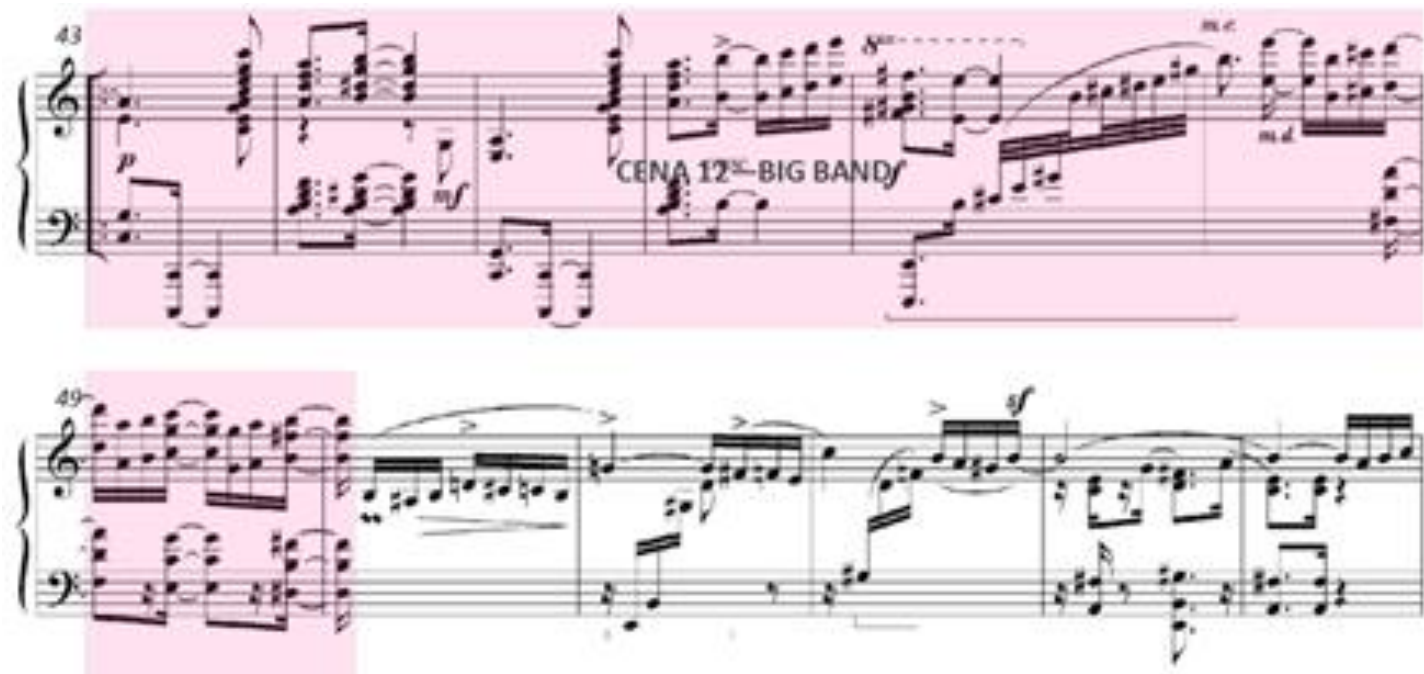

Exemplo 14: Manhosamente, Cena 12, compassos 43-50

A Cena 12 permanece até o compasso 50, onde termina a construção fraseológica. É provável que as oitavas e acordes da mão direita simulem dobramentos (e uníssonos) nas seções de metais - saxofones, trompetes e trombones - e as tríades da mão esquerda, intervenções da base. Almada (2000, p. 227) traz um exemplo semelhante de arranjo para big band com dobramento total (sopros e base), conforme se pode ver no Exemplo 15.

Para Almada "este tipo de textura deve ser guardado para momentos importantes de um arranjo, que necessitem tal ênfase" (op. cit., p.227). No Exemplo 15, as tercinas estão em uníssono ou em oitava nos naipes de sopros. Os trombones dobram os trompetes uma oitava abaixo, e há ataques simultâneos dos sopros e base (guitarra, baixo, piano e bateria) em todos os marcatos: "O trecho acima, uma espécie de convenção, da qual participam todos os instrumentos, é um excelente exemplo de uma das mais poderosas sonoridades que se pode obter com uma big band" (Almada 2000, p. 227). 


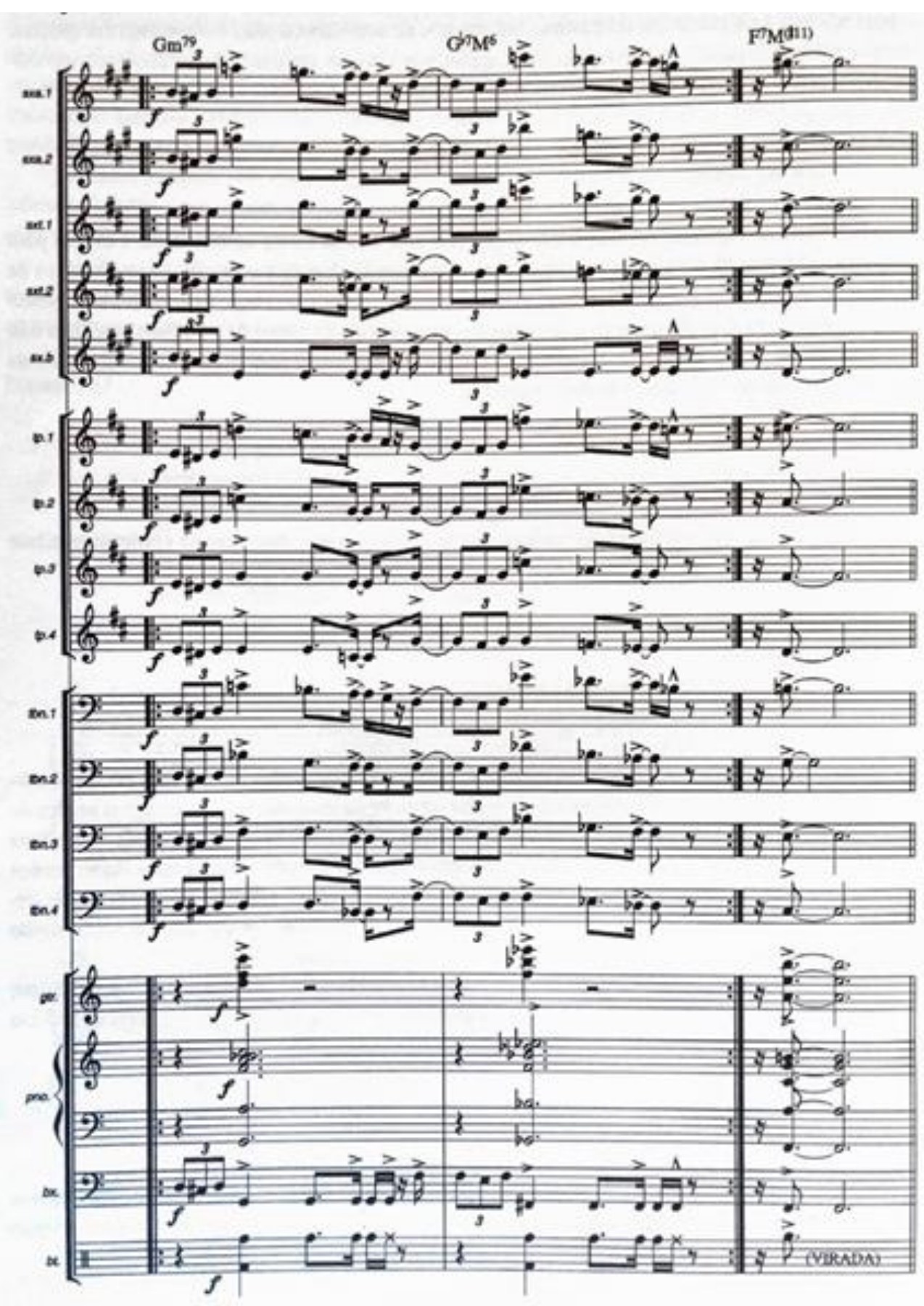

Exemplo 15: Arranjo para Big Band conforme ALMADA 2000, p. 226

A textura que Radamés utiliza na Cena 12 é similar ao caso apontado, tanto pelos ataques aos acordes com ambas as mãos, quanto pelas vozes dobradas em oitavas. Da mesma forma, encontramos diversas síncopas formadas entre a última semicolcheia e a primeira semicolcheia do tempo seguinte, sendo estas antecipações outro ponto em comum. É provável que a opção pelo dobramento em oitava esteja também relacionada ao próprio uso do piano, que comporta muito bem este tipo de escrita. 
$\mathrm{Na}$ Cena 13 seguinte temos um retorno ao choro pianeiro, que permanece até o compasso 62, quando recomeçam os acordes que preparam o reinício da seção B. Como elementos característicos do choro encontramos, com ajuda de Almeida (op. cit., p. 106-141) e Santos (op. cit., p. 7-10), o uso de cromatismos, síncopa e alusão à síncopa, valorização melódica do contratempo, bordaduras e baixo melódico.
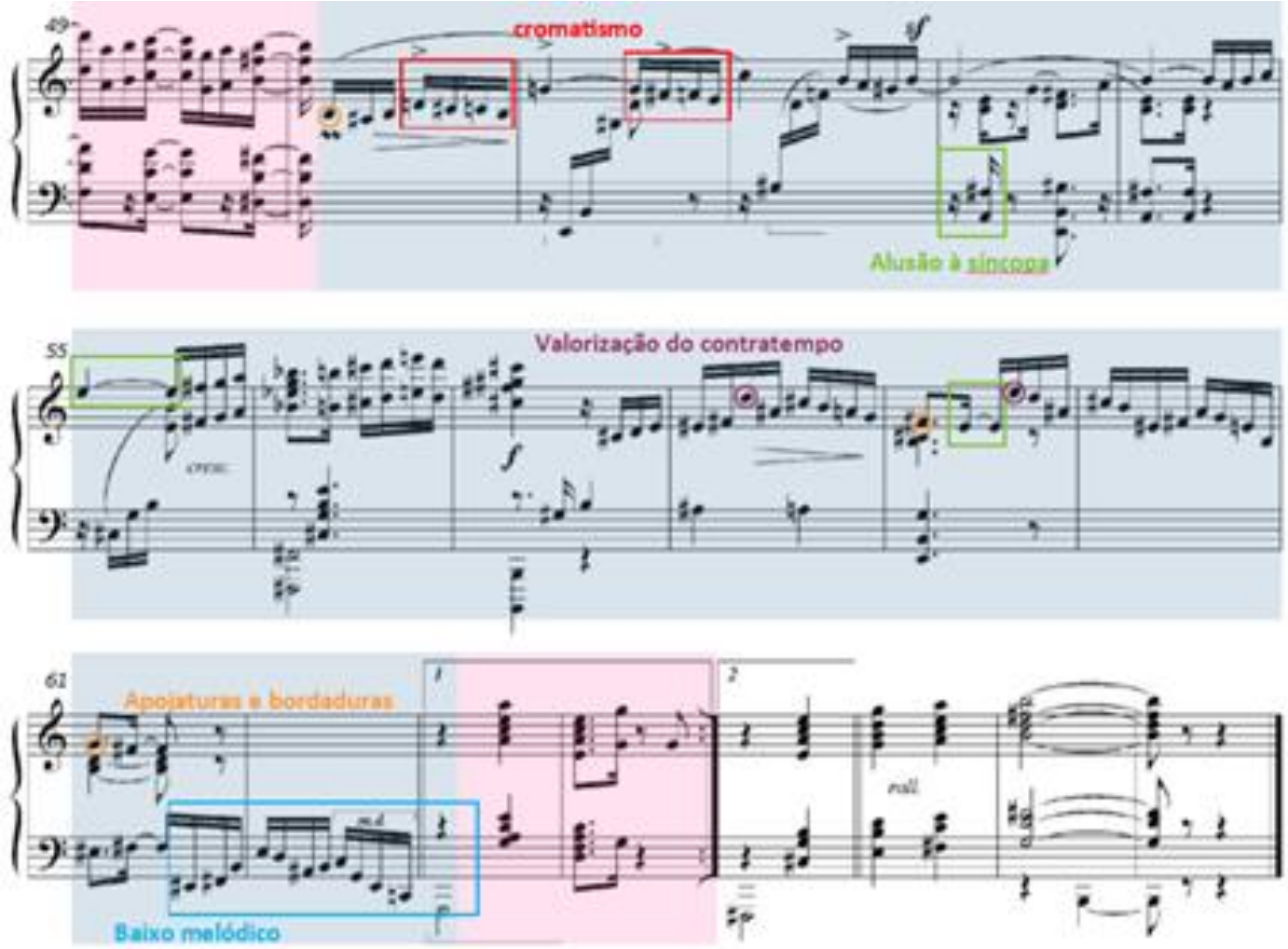

Exemplo 16: Manhosamente, cena 13 - compassos 50-62

Almeida (op. cit) identifica como "alusão à síncopa" as diversas combinações rítmicas que aludem à figuração semicolcheia-colcheia-semicolcheia, onde há a valorização da segunda semicolcheia de cada tempo.

Chega-se então à cena que encerra o choro, que consiste em uma sequência de acordes ascendentes. Santos (op. cit., p. 9) presença de um acorde bII no final do compasso 62, subdominante no encadeamento para Bm6: bII-V-Im, conforme o Exemplo 17.

As notas Dó natural e Dó\# no segundo tempo do compasso acusam a possibilidade de este ser um tertian chord with split chord members, segundo nomenclatura sugerida por Kostka (1990, p. 52). Neste caso, o acorde poderia ser descrito como um $\mathrm{F \# m7(!5)} \mathrm{ou} \mathrm{seja,} \mathrm{um} \mathrm{acorde} \mathrm{que} \mathrm{contém} \mathrm{tanto} \mathrm{a} \mathrm{quinta} \mathrm{justa}$ quanto a quinta diminuta. A presença das duas quintas gera dois trítonos: Dó\#Sol e Fá\#-Dó. No entanto, a movimentação paralela dos acordes e a não resolução destes trítonos por condução de vozes quebram o discurso harmônico funcional. 


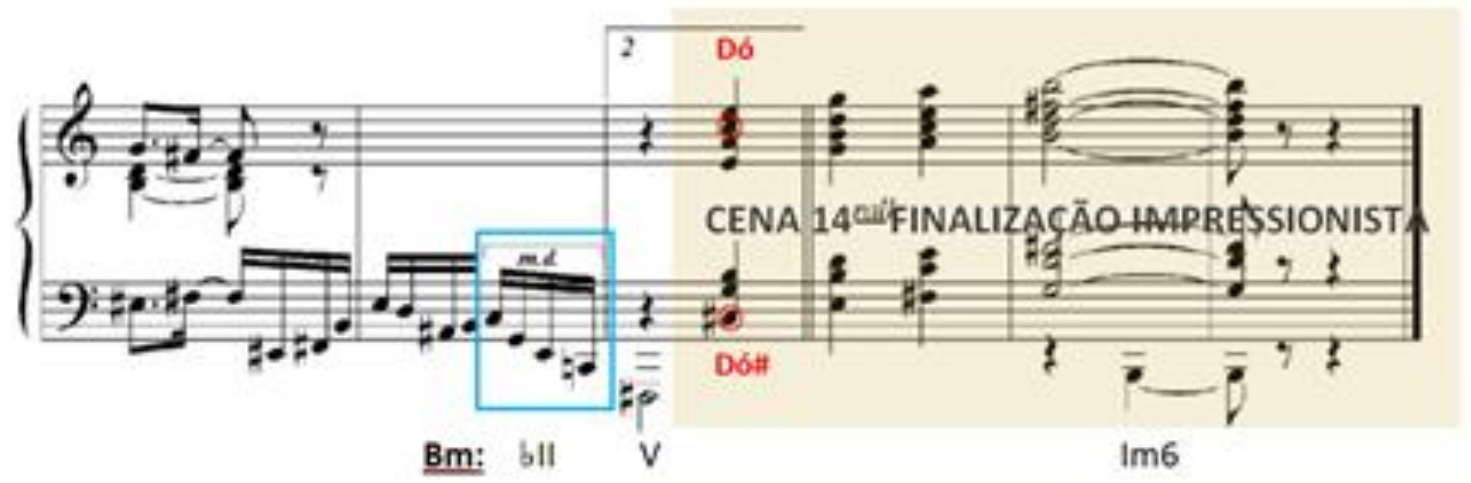

Exemplo 17: Manhosamente, encadeamento bII-V-Im6

Os acordes continuam a se movimentar paralelamente, até atingirem o primeiro tempo do penúltimo compasso. Este acorde, no momento de seu ataque, pode ser interpretado como um G7M; leitura reforçada se considerarmos os dois acordes anteriores, um $\mathrm{F \# m} 7^{\left({ }^{5}\right)}$ e um Em7, sétimo e sexto graus da tonalidade de Sol Maior. Teríamos assim a sequência VIm7-VIIm7( ${ }^{\left({ }^{5}\right)}-\mathrm{I}$ MM ocorrendo em paralelo à proposta anterior ${ }^{4}$.

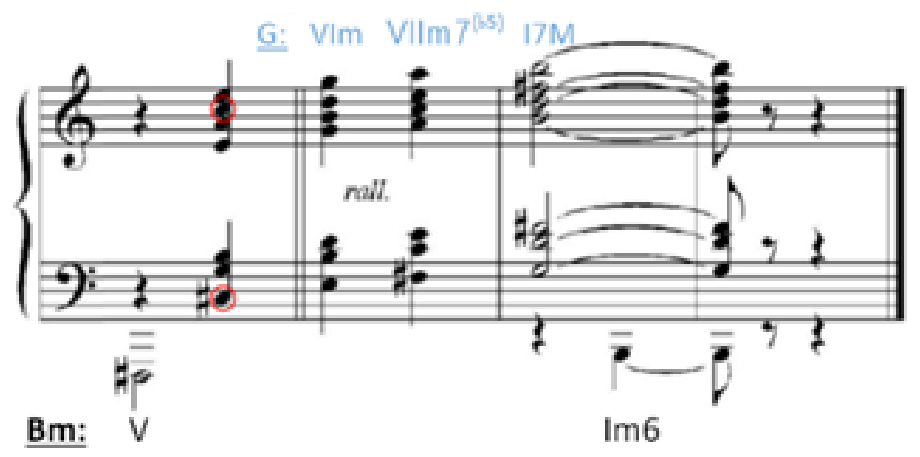

Exemplo 18: Manhosamente, acordes finais - compassos 65-68

Ou seja, ao mesmo tempo em que existe um traçado harmônico que acusa a sequência bII-V-I em Bm, há também um jogo paralelo que mascara a sensação de direcionamento que se esperaria de um encadeamento do tipo assinalado, devido à ambiguidade entre a sonoridade dos baixos e dos acordes de preenchimento. Radamés parece induzir esta escuta a partir da presença do Dó natural e do Dó\# no compasso 65: Dó\# é nota característica da escala de Si menor, enquanto Sol Maior tem a nota Dó natural.

Observando o movimento predominantemente paralelo das vozes nestes últimos compassos chegamos novamente às observações de outrora, sobre a

\footnotetext{
${ }^{4}$ Outra interpretação possível para o acorde de $\mathrm{F} \# \mathrm{~m} 7^{\left({ }^{(5)}\right)}$ seria $\mathrm{D} 7{ }^{(9) / F \# ~(d o m i n a n t e ~ d e ~} \mathrm{G}$ na primeira inversão. Teríamos assim a sequência VIm7-V7(9)-I7M.
} 
influência Debussyniana neste choro. O encadeamento descola os acordes de suas funções dentro do tonalismo tradicional para cumprir outra função - a de criar atmosferas através da apreciação individual de cada acorde. Quando finalmente a nota Si é tocada, quase que como uma brincadeira, o acorde muda de forma e assume finalmente sua identidade de Bm. A sonoridade parece evocar especialmente o prelúdio La Cathédrale Engloutie.

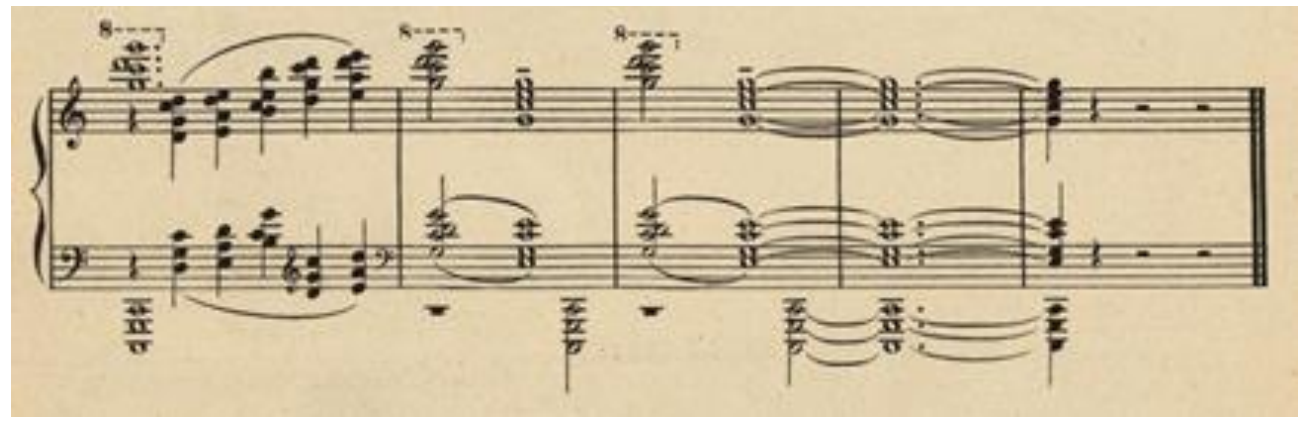

Exemplo 19: La Cathedrale Engloutie (1910), de Claude Debussy, compassos 85-89 Fonte: Ed. Durand et Cie, 1929, p. 42.

Apesar da clara influência impressionista, gostaríamos de reforçar a representatividade do trabalho dos irmãos Gershwin ${ }^{5}$ no desenvolvimento de uma sonoridade que se consolidou como característica dos filmes e musicais da Broadway (e filmes musicais) ainda na primeira metade do século XX. Os três estudados na dissertação fazem certa referência à esta sonoridade nas cenas finais. A associação da Cena 14 com um uso impressionista da harmonia é caminho comum entre as composições de George Gershwin e Radamés, ambos influenciados pela obra de Debussy ${ }^{6}$. A figura seguinte foi retirada de um trecho do famoso poema sinfônico Um Americano em Paris composto em 1928 por George Gershwin7, que apresenta uma finalização semelhante à utilizada por Radamés (vide Exemplo 20).

${ }^{5}$ O irmão mais velho de George, Ira Gershwin (1896-1983), foi um letrista norte-americano. Juntos produziram diversos sucessos da Broadway: “George e Ira Gershwin serão sempre lembrados como o time cuja voz era sinônimo dos sons e estilo da Era do Jazz" (no original: "George and Ira Gershwin will always be remembered as the songwriting team whose voice was synonymous with the sounds and style of the Jazz Age" (www.gershwin.com).

${ }^{6}$ Ver Pollack (2006, p. 29)

7 Posteriormente, em 1951, foi lançado um filme musical de mesmo nome. A trilha, escrita pelos irmãos Gershwin, inclui as famosas canções I Got Rhythm (1930) e The Man I Love (1927) com letras de Ira Gershwin. 


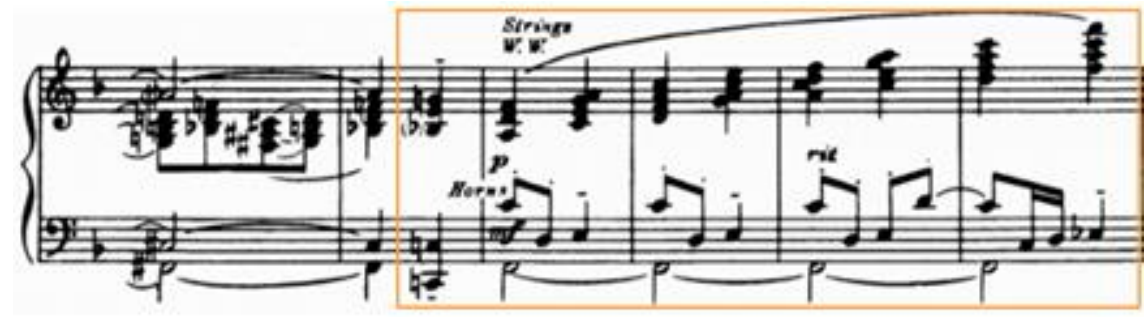

Exemplo 20 - An American in Paris (1928), de George Gershwin - compassos 103-108 Transcrição para piano de William Daly. Fonte: New World Music Corporation, 1929

\section{4 - Considerações sobre os Choros}

\section{1 - Sobre o revezam ento de poses enquanto regra de composição}

A síntese estilística de Radamés parece se realizar através do equilíbrio entre semelhança e diferença. Há diferentes graus de ruptura e contraste entre as cenas, visto que alguns materiais são mantidos na passagem entre elas, enquanto os demais elementos mudam ao seu redor. Os elementos escolhidos pelo compositor para serem mantidos variam, e as semelhanças ocorrem por associações diferentes: podem ser aproximações por contorno melódico, por região do teclado (timbre e posicionamento da mão, o que revela um aspecto apoiado na prática instrumental), por tratamento harmônico, por textura, etc.

Assim, quando o compositor opta por manter uma das características mais proeminentes da cena e alterar elementos de menor destaque na cena seguinte, a sensação de ruptura é menor. Por outro lado, quando este opta por fazer uma mudança brusca em um elemento que estava em primeiro plano no reconhecimento de determinada cena, a percepção de ruptura é maior. De maneira semelhante ao que ocorre no movimento narrativo da obra de Machado, qualquer elemento parece ser passível de fazer a conexão entre as cenas. Igualmente pode-se mudar de assunto sem aviso prévio nem transição, um exercício de volubilidade por parte do compositor.

Olhemos outra vez para o choro Manhosamente (páginas 9 e 10). Os principais elementos comuns entre as primeiras três cenas são os acordes formando intervalos de décima na mão esquerda, que acompanham o movimento melódico da mão direita, e as quatro primeiras notas da melodia, que apresentam o motivo que será reapresentado em estilos diferentes (cena 2 Debussy e cena 3 - Na noite). O contorno melódico "chorão" da cena 1 é mantido no primeiro compasso da cena 2, porém agora escrito na região central do piano. Apesar da mudança de timbre da região aguda para a região central, a manutenção da semelhança do contorno melódico e das funções da voz superior (melodia) e dos acordes da mão esquerda (acompanhamento harmônico) ameniza a ruptura com a cena anterior. Os acordes em décima se movem 
igualmente para a região central no começo desta cena, porém logo no segundo tempo do compasso seguinte assumem outro papel ao se movimentarem melodicamente, ascendendo paralela e cromaticamente, dando forma à sonoridade impressionista. À medida que o estilo se transforma, a impressão é de que a música está se afastando da sua proposta inicial. Antes de dar tempo de compreender exatamente o que aconteceu, a terceira cena rompe com a anterior a partir da relação dominante $\rightarrow$ tônica explícita entre os acordes de B7 ${ }^{(b 9)} / \mathrm{D \#} \mathrm{e}$ C/E e o ouvinte é levado novamente para outro ambiente.

Outra vez a expectativa de estabilidade é rapidamente frustrada, tanto pelas características da própria cena 3, quanto pela entrada da cena 4 (Gershwin). Esta última acelera o ritmo harmônico, desloca acentuações e prepara a dominante que será prolongada na Cena 4, com resolução somente na Cena 6.

A sensação de ruptura imediata entre a Cena 1 e a Cena 2 é menor do que entre a Cena 2 e a Cena 3, já que no primeiro caso a semelhança da relação entre melodia e acompanhamento é inicialmente mantida. No segundo caso, a Cena 2 já havia diluído parcialmente o funcionamento tonal dos acordes. Então quando a relação dominante $\rightarrow$ tônica é expressa categoricamente entre os compassos $9 \mathrm{e}$ 10, e a melodia da mão direita retorna à oitava superior, a mudança de pose é mais brusca.

Por fim, o que mais nos interessa sobre as considerações feitas até o momento é perceber que o resultado sonoro dos choros é essencialmente uma sucessão de figuras conectadas em sequência. Radamés parece realizar "colagens" de estilos variados, para além de um suposto desenvolvimento dos materiais ou uma estrutura de tema e variações. Este caráter rapsódico dos choros apresenta recortes musicais com inúmeras vinculações, em uma dinâmica de revezamento de poses que expõe um Radamés multifacetado e contraditório, cuja poética declara a existência de contrastes permanentes.

\section{2 - Sobre o elemento nacional nos choros}

Ao que nossas análises apontam, Radamés posa igualmente de pianeiro, pianista de stride, pianista "da noite", virtuose Romântico; impressionista; "moderno", "tradicional"; "erudito", "popular", "jazzista"; arranjador de big band, compositor de trilha sonora, orquestrador ${ }^{8}$. Todas facetas transparecem sem exclusão, sendo os choros aqui estudados o somatório de todas estas figuras, cujo resultado não é homogêneo, e sim fragmentário. Tal revezamento de poses, que apontamos anteriormente como um exercício de volubilidade, leva o ouvinte a uma busca constante de compreender e classificar o autor, que foge a qualquer possibilidade concreta de rotulagem.

8 Ver análise dos demais choros para cenas que não estão presentes em Manhosamente. 
Cria-se entre autor e leitor uma relação defacto, uma luta pela fixação do sentido e também pela rotulação recíproca - que espécie de manhoso é esse narrador? que espécie de infeliz é este leitor? (...) a representação flui francamente no elemento da vontade, ou melhor, do arbítrio, e a objetividadeé no máximo uma aparência (...) (Schwarz 2012, p. 24).

O choro como um dos principais representantes da música instrumental dita brasileira não encontra aqui uma representação que pretende um apaziguamento a partir da anulação das contradições. Ao invés, as expõe ao coloca-as lado a lado, cena a cena. Tais contradições, conforme discutido no começo deste artigo, parecem apontar para uma maneira pela qual o compositor lida com o aspecto identitário nacional.

As poses enumeradas no primeiro parágrafo apontam para uma variedade de associações implicadas em questões mais profundas no que tange à própria ordem social vigente na sua época. A começar, há a dicotomia entre modernidade e tradição, que pode ser percebida mais diretamente nas categorias com rótulos relacionados ao choro: choro pianeiro, choro moderno, chororagtime/stride e baixaria. Enquanto o choro pianeiro e a baixaria apontam para características mais facilmente associadas ao choro do século XIX e primeiras décadas do século XX - o suposto choro "tradicional" -, as demais categorias apontam para inovações a partir deste.

Já a questão das referências jazzísticas nos rótulos "moderno" e "ragtimestride" aponta para um duplo problema: o jazz enquanto influência estrangeira e, ao mesmo tempo, modernizadora. Aqui identifica-se um nó, pois esta característica serve tanto a valorizar quanto desacreditar a obra de Radamés. Ao mesmo tempo que, à época, os Estados Unidos eram vistos como uma "naçãomodelo", valer-se de referências ao jazz implicaria também em uma suposta negação (ou traição) do nacional de acordo com os moldes do nacionalismo andradiano. Analogamente, os arranjos em estilo big band já haviam se consolidado na música brasileira principalmente junto ao samba em décadas anteriores à composição dos choros investigados. Aqui novamente a dupla referência: a escrita para big band representa o jazz, estrangeiro, e conjuntamente representa o samba, nacional, em sua versão "modernizada".

Ao mesmo tempo há a questão do jazz enquanto música popular, que traz a oposição com em relação ao rótulo erudito. Esta oposição pode ser encontrada também na figura do próprio choro, assim como nas referências a estilos que vieram a se consagrar em grande parte através do cinema, da radiodifusão e do mercado fonográfico de maneira geral. No que diz respeito à erudição, os choros analisados lançam mão de referências orquestrais, referências ao impression ismo francês e a arpejos e escalas de efeito popularizadas no período Romântico. Em paralelo corre a questão do virtuosismo pianístico que é insinuado na execução das peças. É igualmente notável o fato de que na década da composição dos 
choros, o elemento estrangeiro sujeito a crítica é a referência à música norteamericana, enquanto os gêneros e estilos de tradição europeia são paradoxalmente tidos como referências de erudição e tradição.

Para "engrossar o caldo" podemos refletir sobre associações entre os estilos enumerados de forma mais geral. Fazendo referência primeiramente ao choro pianeiro, ao ragtime e ao stride, é possível considerar que estes são estilos que se consolidaram no mesmo instrumento, portanto existe uma questão técnico-mecânica que diz respeito ao próprio tocar (à maneira de lidar com o instrumento) que se reflete no repertório composto. Outro ponto é que são oriundos basicamente da mistura entre danças de salão europeias com músicas e danças de origem africana, além de serem contemporâneos. Estes estilos ${ }^{9}$ circularam durante muito tempo tanto em forma de partitura quanto através de músicos que tocavam de ouvido, como acompanhadores, como parte de conjuntos ou ainda como solistas. São, essencialmente, estilos urbanos que possuem conexões comuns com o repertório de salão europeu.

A influência impressionista, conforme comentado nas análises, foi reconhecida em estudos anteriores na obra de Gershwin ${ }^{10}$ assim como na obra de Radamés, e contempla um repertório que está vinculado à herança musical europeia. Mais precisamente, na primeira metade do século XX está vinculado também a um ideal de cultura francês. O uso de escalas e arpejos de efeito virtuosístico foi amplamente difundido no período Romântico por compositores como Franz Liszt (1811-1886), Frédéric Chopin (1810-1949) e Johannes Brahms (1833-1897), porém foram igualmente utilizados por pianistas de stride e pelo showman Liberace (1919-1987). Este último atingiu o auge de sua fama a partir da

\footnotetext{
${ }^{9}$ Não nos propomos a entrar no mérito da questão do choro enquanto gênero ou estilo, já que o presente trabalho se refere intencionalmente a traços estilísticos do choro. Porém gostaria de remeter novamente ao trabalho de Moura (2012, p. 11), que discute a questão sob o ponto de vista histórico sobre o termo: “O termo Choro, portanto, primeiramente serviu para designar uma formação instrumental, posteriormente um estilo interpretativo e finalmente um gênero musical. Embora o emprego do termo apenas como forma de designar uma formação instrumental já não seja aceito desde o começo da história do gênero, as noções do Choro como gênero e estilo, sempre estiveram muito próximas. Isso se deve à importância do estilo interpretativo dos Chorões para compreensão do gênero. Essa característica particular de interpretação possibilitou ao músico de Choro a possibilidade de apropriação de outros gêneros e estilos. Esse procedimento será chamado de "toque de Midas", em alusão ao personagem da mitologia grega, que transformava tudo o que tocava em ouro, ao passo que o Chorão o transforma em Choro".

10 "For his part, Gershwin denied ever playing "very serious things" as a piano student, though he told Monfried, "Hambitzer familiarized me with the music and the composers who have shaped my career - Liszt, Chopin and Debussy." (...) Gershwin's even closer ties with Debussy involved not only the appropriation of parallel harmonies, mixed orchestral colors, and other stylistic devices, but his basic working method of allowing melody free rein, supported by unconventional harmonies; (...)" (Pollack 2006, p. 28).
} 
década de 1950, no entanto sua carreira já se formava desde o final dos anos 1930. Esta associação é pertinente devido à sua representatividade como pianista cujo estilo marcou a indústria fonográfica e cinematográfica não somente norteamericana, porém internacional, além de apontar para outro paralelismo entre estilos geograficamente afastados.

Da mesma maneira, o jazz em suas mais variadas formas, assim como o choro e o samba, fez parte da própria história do cinema e da radiofonia das Américas. Assim, a associação do jazz, do choro e do samba como gêneros populares tem lastro também na associação com as mídias massivas. A lembrar que a Política da Boa Vizinhança foi uma iniciativa que teve início em 1933 - pelo menos dez anos antes da composição dos choros que analisamos- e que aproximou os ouvidos e olhos brasileiros e norte-americanos. A questão, portanto, não é buscar apontar obstinadamente as origens de determinado elemento presente nos choros, mas de compreender o uso que Radamés faz deles.

O instinto de nacionalidade reconhecido por Schwarz na obra de Machado de Assis assim se revela nos choros Manhosamente, Canhoto e Negaceando; através do caráter volúvel assumido pelo compositor. De maneira semelhante às Memórias, o efeito não está nos materiais e técnicas tomados em separado, mas na súbita intimidade que se estabelece entre eles, e na sua sucessão; sendo que o resultado musical depende da vivacidade e da frequência dos contrastes. $\mathrm{O}$ intuito é mostrar superioridade através da destreza da fala, do domínio do vocabulário e da amplitude de assuntos tratados. Há ainda outro fator importante na caracterização dos choros de Radamés, que se assemelha às Memórias: a existência de certo "virtuosismo retórico de um gentleman erudito" que cede à permissividade para tratar de qualquer assunto, bem como conectar temas de maneira despreocupada. Este virtuosismo retórico é também uma estratégia de mascaramento do propósito e do aspecto "popular" do choro enquanto identificação. Está relacionado à ambivalência ideológica das elites e se configura em forma de dilema, pois Radamés não assume totalmente nenhuma das identidades que propõe. "Qual das fisionomias de Brás é a verdadeira? Está claro que nenhuma em particular" (Schwarz 2012, p. 23). É justamente este o aspecto que configura o nacional mediatório que tentamos ilustrar neste estudo. O resultado estético dos choros, de forma semelhante ao movimento proposto nas Memórias, imita e reflete as particularidades das relações sociais brasileiras, cuja complexidade está manifesta neste nacional profundo, conflitivo, contraditório e ambíguo. 


\section{Referências}

1. Almada, Carlos. 2000. Arranjo. Campinas: Ed. da UNICAMP.

2. Almeida, Alexandre Zamith. 1999. Verde e Amarelo em Preto e Branco: as Impressões do Choro no Piano Brasileiro. Dissertação de Mestrado. Campinas: UNICAMP.

3. Assis, Machado de. 1994 [1881]. Memórias Póstumas de Brás Cubas. Rio de Janeiro: Editora Nova Aguilar.

4. Borelli, Helvio. 2005. Noites Paulistanas: Histórias e Revelações Musicais das Décadas de 50 e 60. São Paulo: Arte e Ciência.

5. Debussy, Claude. 1910. La Fille aux Cheveux de Lin. Prelúdio VIII, Livro 1. (Partitura). Paris: Durand \& Cie., p. 31-32.

6. . 1910. Voiles. Prelúdio II, Livro 1. (Partitura). Paris: Durand \& Cie., p.3-6.

7. 1910. La Cathedrale Engloutie. Prelúdio X, Livro 1. (Partitura). Paris:

Durand \& Cie., p. 23-26.

8. Florenzano, Modesto. 2007. Sobre as Origens e o Desenvolvimento do Estado Moderno no Ocidente. Revista de Cultura e Política no71. http://www.scielo.br/pdf/ln/n71/01.pdf

9. Fujiyama, Laís D.; Mendes, Joel Carlos S. V. 2013. Propostas de Revisão da Transcrição para Duo de Violões da Obra Canhoto, de Radamés Gnattali. Revista Vórtex, n.2, p.144-156.

10. Gershwin, George. 1929. An American in Paris. (Partitura). Transcrição para piano de William Daly. New York: New World Music Corporation.

11. . S/D. Concerto in F for Piano and Orchestra. (Partitura). Transcrição para dois pianos a quatro mãos. New York: Windsor Editions.

12. Gnattali, Radamés. 1943. Canhotom - choro para piano solo. Partitura em pdf editada a partir do manuscrito original, disponibilizado por Nelly Gnattali. 
13. . 194-?. Manhosamente - choro para piano solo. Partitura em pdf editada a partir do manuscrito original, disponibilizado por Nelly Gnattali.

14. . 194-?. Negaceando - choro para piano solo. Partitura em pdf editada a partir do manuscrito original, disponibilizado por Nelly Gnattali.

15. Meyer, Leonard B. 1996. Style and Music: Theory, History and Ideology. Chicago: The University of Chicago Press.

16. Moura, Rafael Ferraz Marcondes de. 2012. O Toque de Midas do Choro: Estabilidade e Fricção sob a luz das tópicas. Dissertação de Mestrado. Brasília: Universidade de Brasília.

17. Pinto, Alexandre Gonçalves. 2014 [1936]. Choro: Reminiscências dos Chorões Antigos. Rio de Janeiro: Acari Records.

18. Pollack, Howard. 2006. George Gershwin: his Life and Work. Berkeley: University of California Press.

19. Pronsato, Carla Veronica. 2013. Os Choros para Piano Solo Canhoto e Manhosamente de Radamés Gnattali: Um Estudo sobre as Relações entre Música Erudita e Música Popular. Dissertação de Mestrado. Campinas: UNICAMP.

20. Santos, Rafael dos. 2001. Análise e Considerações sobre a Execução dos Choros para Pano Solo Canhoto e Manhosamente de Radamés Gnattali. Per Musi, v.3.

21. Schwarz, Roberto. 2012. Um Mestre na Periferia do Capitalismo: Machado de Assis. $5^{\underline{a}}$ ed. São Paulo: Ed. 34.

22. Zorzal, Ricieri Carlini. 2005. Dez Estudos para Violão de Radamés Gnattali: Estilos Musicais e Propostas Técnico-interpretativas. Dissertação de Mestrado. Salvador: UFBA. 